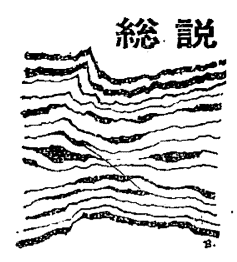

\title{
結晶性高分子の延伸に伴う
}

構造変化

一特にネッキング発生までの領域について—

\begin{abstract}
結晶性高分子固体の変形に伴ら構造変化を明らかにすることは，結晶性高分 子の一次元あるいは二次元炡伸加工された繊維あるいは皮膜成形品の物理 的, 力学的性質を理解する上に, あるいはそれらの製造工程の管理の上に重要 であるばかりでなく，逆に結晶高次組織（たとえば球晶組織）といった複雑な 構造の解析手段としても重要な課題である。したがって現在委でこの方面の研 究は多くの手段により数多くなされている。最近では結晶性高分子の単結晶の 変形を通じて, 結晶部分の基本的な変形機構が次々と解明されつつある。しか しながら通常の皮膜あるいは成形物は何らかの結晶高次組織を含み, その結晶 部分の構造はかなり明確となってきたが，非晶部分あるいは非晶部分と結晶部 分との相互関係といった構造的飞依然として不明確な部分を含み, 単結晶の変 形の知識を巨視状固体のそれに導入するにもその道ははるけくも遠い現状にあ る。この小稿では前半は結晶性高分子の変形機棈を結品高次組織（主として球 晶）を中心に,ネッキングが発生するまでの変形領域について現在までなされ た多くの研究の整理を試み, 後半は形態学的な知見と微結晶掞よび非結晶鎖の 配向挙動との関連性あるいは力学的性質の理諭的な解析への糸口として球晶変 形のモデル的取报について記したい。
\end{abstract}

小田隆*河合弘 赵**

\section{1. 序説}

結晶性高分子固体の変形過程はきわめて複雑である。 その原因は種々考觉られるが，その第一は構造がきわめ て複雑であること，第二は変形に対する条件因子が多い ことによる現象の多様性である。したがって結晶性高分 子固体の変形を考察する場合，構造面に执いては種々の 大きさの構造単位（たと党ば球唱，微結晶ラメラ）を基 準に検討する必要があるであらう。一方変形に対する条 件の面からは，できるだけ単純な条件在選ら゙べきである う。ここでは一乹延伸（または変形）にかぎりネッキン グが発生するまでの延伸領域を中心として種々の大きさ の構造単位を基準に整理検討を試みた。

* Takashi ODA 名古屋工業大学 (緎維高分子工学 科・名古屋市昭和区御器所町) 助教授 - 工博

** Hiromichi KAWAI 京都大学 (工学部高分子化学 教室・京都市左京区吉田泉殿町) 教授・工博

Structural Change during Uniaxial Stretching of Crystalline Polymers

-Deformation Mechanism within the Beginning of Necking-

\section{1-1. 結晶性高分子固体の構造}

結晶性高分子固体の構造に関してはすでに多くのすぐ

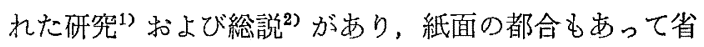
略したい。一般に結晶性高分子を溶融状態あるい濃厚 溶液から皮膜あるいは成形物に作成する場合，特別な条 件下でないかぎり結晶性の低い埸合を除いて球晶組織が 生成する。球晶は最も成長速度の速い結晶軸を半径方向 として放射状に成長した微結晶ラメラからなる。さらに 微結晶ラメラ間, 微結晶ラメラ内就よび球晶間には，特 そらく不規則な分子鎖の折れたたみによる結晶ラメラ表 面の大きなループあるいは結晶ラメラ間の連結鎖（tie chain）として，また分枝，分子末端，不純物あるいは 低分子物の集まりとしても非晶領域が存在すると考えら れ変形に際して大きな役割を演ずるであるう。

\section{1-2. 変形に影響を及(゙す諸因子 ${ }^{32}$}

結晶性高分子固体の变形心影響を及ぼす諸因子を第 1 表に示す。このうち変形速度の影響については, 最近急 速に進展した Reo-optics といら学問分野で詳細にとり あっかわれるよらになっだっ。

ここでは問題を複雑にするので変形速度の影響につい 
第 1 表

\begin{tabular}{|c|c|c|}
\hline $\begin{array}{l}\text { ポリーの物理的 } \\
\text { 化学的性質 }\end{array}$ & $\begin{array}{l}\text { ポリマーの成形 } \\
\text { また成膜条件 }\end{array}$ & $\begin{array}{l}\text { ポリマー皮膜およ } \\
\text { び成形物の変形条 } \\
\text { 件 }\end{array}$ \\
\hline $\begin{array}{l}\text { 主鎖桼よび側鎖の } \\
\text { 化学組成 }\end{array}$ & 結昆化温度 & 変形速度 \\
\hline 分子量分布 & 冷却速度 & 変形温度 \\
\hline $\begin{array}{l}\text { 分 枝 度 } \\
\text { 立体規則性 }\end{array}$ & $\begin{array}{l}\text { 経時効果 } \\
\text { 後熱処理条件 }\end{array}$ & $\begin{array}{l}\text { 変形様式 (一軸, } \\
\text { 二軸伸㖘, 王縮, } \\
\text { その帒) }\end{array}$ \\
\hline
\end{tabular}

てはふれない。また二軸変形については現在なお基礎的 な研究が乏しぐ省くことにした。

\section{1-3. 測定方法}

第 2 表に測定方法と刘象となる構造単位について示し た。最近では多くの測定方法を併用することにより総合 的な検討が行なわれるらになっだ 然として非晶部分に対して明確な知見を与兄る測定方法 のないことが結晶性高分子の変形機構について推論を多 くしている。

\section{2. 結晶性高分子皮膜および成形物の延伸に伴う球 晶の形態学的变化}

皮膜あるいは成形物を延伸した場合，その内部の変形 についてはとの大きさ和よび形態から球晶の変形をとら えるのが最もわかりやすい。したがってをず光学顕徽鏡 挌よび電子顕微鏡観察による形熊学的な变化について述 ベる。

\section{2-1. 球晶の变形様式の形態学的な分類 ${ }^{6}$}

結晶性高分子固体が球晶を含さ場合, 試料により変形 条件により現われる変形様式が異なる。最近 Hay 扎よ び Keller は比較的薄い皮膜状試料のほぼ一軸延伸を通 じて二次元円船状の球晶の变形様式を形態学的に分類し た。

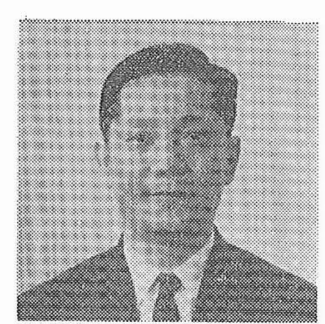

河合弘帛氏 炤和 18 年東京工業 大学紡織学科卒業, 同年東洋紡綃 (侏) 守的科学 研究所化勤務, 炤和 21 年 3 月京都少国大学助乎となり， 以来工学部瀻維化学教室, 高分子化 学教室に勤務, 現在に至る。 趣味はレコードをきくた为の音響 再.生の電気回路の組立にこったこと もあるが, 現在はめんどうくさくっ てだめ。

小田 隆氐 炤和 37 年京都大学 工学部淌分子化学科卒業, 昭和 42 年 同学工学矼究科博士樑程終了, 同年 4 月同学工学部助手, 噪和 43 年 4 月 名古屋工業大学瀻維㬏分子工学科に 勤務，現在米国マ声ューセッツ州 立大学高分子研究所比留学中。専攻 は高分子物理（特に Reo-optics） 趣味注水泳, 音楽, 絵而観営なと

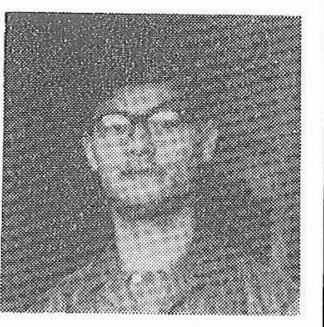

\begin{tabular}{|c|c|}
\hline 測定方法 & 観測される変形または変化 \\
\hline 広角 X 線回折 & $\begin{array}{l}\text { 結晶格子ひずみ, 徽結晶の寸法, 結晶形 } \\
\text { 軽拮晶配向, 緋結鎖向 }\end{array}$ \\
\hline 小角 X線 & $\begin{array}{l}\text { 長周期 (結晶ラメラ十非結晶相)，長周 } \\
\text { 期の配问 }\end{array}$ \\
\hline 光散乱 & $\begin{array}{l}\text { 球㫛外形寸法, 結晶光軸の配向, 結晶 } \\
\text { ×ラのよじれ周期 }\end{array}$ \\
\hline 電子顕微鏡 & $\begin{array}{l}\text { 結晶ラメラおよびラメラ間, 単結晶, 球 } \\
\text { 晶 }\end{array}$ \\
\hline 電子線回折 & $\begin{array}{l}\text { 結晶格子ひずみ, 結晶形枟換, 双晶化, } \\
\text { 結晶配向 }\end{array}$ \\
\hline 赤外線四収 & $\begin{array}{l}\text { 分子鎖の configuration, 結晶和よび非 } \\
\text { 結晶鎖の配向 }\end{array}$ \\
\hline 光学顕微鏡 & 球晶，分子鎖光軸の配向 \\
\hline $\begin{array}{l}\text { ケイ光および可視 } \\
\text { 光二色性 }\end{array}$ & 非結昆鎖の配向 \\
\hline
\end{tabular}

i. Inhomogeneous deformation

a. between spherulites (Fig. 1, a) $)^{6), 11,14)}$

b. within a spherulite (Fig. 1, c) ${ }^{6), 10), 12)}$

ii. Homogeneous deformation (Fig. 1, b) ${ }^{6), 12)}$

iii. High elongation ${ }^{2), 13)}$

a. crack formation, b. fibrillation

iv. Brittle fracture

a. between spherulites ${ }^{10), 11}$

b. within a spherulite ${ }^{10), 11)}$

一般的には i と ii の中間的な变形が多い。以下に i 拈よび ii について説明する。上の分類の諸例は右肩の 文献を参照されたい。

\section{2-2. Inhomogeneous deformation}

皮膜および成形物の一軸延伸に伴い内部の球晶が不均 一に变形する場合である。この不均一性は球晶内で起こ る場合と球晶間で起こる場合とに分類される。

二次元の球晶間の不均一変形は主として延伸方向に垂 直ないし垂直に近い境界で降伏領域が拡張され次第に球 晶間を拡げる。通常降伏領域の球晶内への拡張は顕著で ない。また降伏領域は極端に厚みが減少する。しかしな がら三次元的ないしは三次元球晶においては二次元球晶: のような極端な球晶間降伏は起こらず，延伸方向に垂直 に近い球晶間で延伸方向に分子鎖軸が極端に配向したフ ィブリル状物を生成することが電子顕微鏡により認めら れている2゙。

球晶内で起こる不均一変形は球晶中心を含む直径で起 こる場合と球晶中心を含まない場合にわけられる。延伸 方向に垂直な球晶中心を含む直径で起こる不均一変形は 最初 Keith 扎よび Padden によって polyethylene(以 下 PE と略す) 球晶について報告されの), 変形に際して 延伸軸に垂直な直径に鋭い降伏が起こり，延伸率の増加 とともに降伏領域は拡張されていく。したがって同一球 晶内の二つに分かれた未变形部分は減少しながらその間

「高分子」 1969 
隔が開いていく。ここで顕著なことは降伏 領域にも消光縞が残存する事実である。こ れは何らかの形で原組織が保存されながら 変形することを喑示している(たとえば結 晶ラメラのラメラ軸まわりのねじれ)。さ らに球晶中心が長く引き伸ばされることか 占球晶中心付近は応力に対し变形しやすい と考党られる。

一方, 小林らは電子顕微鏡によって水面 膜として生成した PE 二次元球晶が常温で 延伸されると延伸方向に垂直な方向に球晶 中心が通らない幾本ものき㣗つを生じ, 延 伸率の增加とともにきれつは昖張され球晶 粉砕されたようになることを観察した（第 2 図)。また同じ水面膜を高温で延伸すると 主として側面が比較的均一にのび延伸方向 に長いわらじ状になるのが認められた（第 2 図)。この変形に拈いても球晶中心は長 く引き伸ばされ中心の長く伸びた線にそっ てさけ目を生じることが認められた ${ }^{12) 。 ~}$

球晶内不均一変形においてもとして球晶 側面に見られる変形は少なくとも変形の初 期において球晶の半径方向の結晶軸（たと えば PE ではb軸)まわりの結晶ラメラの 回転および結晶ラメラ間の相互すべりとし て解釈されるであろう。球晶間および球晶 内のいずれの不均一変形において子変形さ

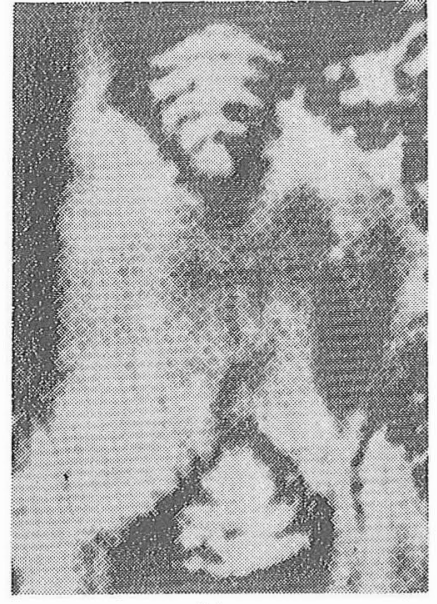

(a)

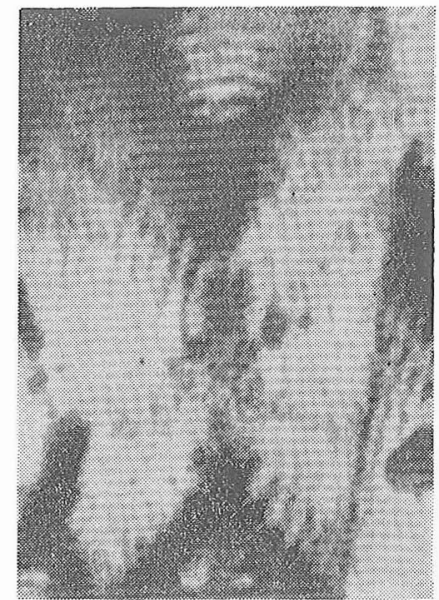

(b)

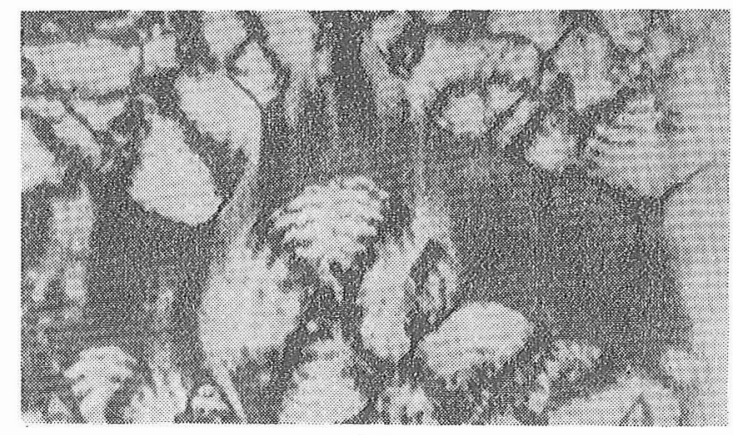

(c)

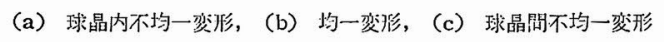

第 1 図 3 種の球晶変形様式, Kolloid-Z., 204, 43 (1965)

れた領域は小林により PEについて示されたように, 延 伸方向に結晶分子鎖すなわち結晶 $\mathrm{c}$ 軸が極端に配向して いる ${ }^{13)}$ 。また球晶間変形においては Ingram-Peterlin

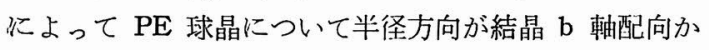
ら結晶の $\mathrm{c}$ 軸配向への転換が認められている ${ }^{14)}$ 。これら の変形では少なくとも，結晶ラメラ(折りたたみ結晶) のときほぐし，あるいはへき開のような結晶配向を急激 変化させる变形機構が支配的であらう。

\section{2-3. Homogeneous deformation}

ここでいう変形は戦密に均一ではなく，巨視的に void の生成あるいはネッキングの発生を伴わない一様な変形 である。

通常結晶性の”顕著に高くない高分子（たとえば分枝 PE, tacticity のやや低いPPなど) から作成された球 晶を含む皮膜の変形あるいは結晶性が高い高分子でも変 形率が小さい範团内で，膨潤下および高温下での変形に おいては比較的均一変形が得やす(6),12)。また高分子皮 膜内で媒体中に孤立して生成した球晶も比較的均一に変 形する ${ }^{15)}$ 。

微視的観点からはともかくとして, 球晶の消光リング がー様に連続的なダ円形になる場合でも延伸軸に平行な
直径は他の直径に 比べて交形しがたいことが認められ る。未変形時の球晶も結晶の最も成長速度の速い刺を半 径方向にして中心から放射状に結晶ラメラが成長してお り, 球晶内の局所的な結晶配向あるいは变形挙動は不均 一となるが，一般に球晶間に特に降伏しやすい箇所があ る場合は別として, 球晶内の微結晶の移動は比较的均一 に起こっていると考兄られる。三次元球晶によって充テ ンされた皮膜がー一軸延伸された場合の球晶の変形につい てはCrystal および Hansenにより, $\mathrm{PP}^{17)}$ および Nylon

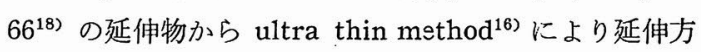
向に平行㧍よび垂直に切り出された試片の光学拈よび電 子顕微鏡観察から, 球晶がフットボール型, すなわち 回転ダ円体型に変形することが示された（第３図）。さ らに変形した球晶間の境界線が拡げられ球晶間の相互移 動のあることを推察した。

また溶融状態から自由表面で生成した球晶を一軸变形 した試片の電子顕微鏡写真および光学顕微鏡写真は環状 の凹凸縞が一様にダ円形になっていることを示すと同時 に, 縞の間隔が延伸方向に拡がりその垂直方向では狭く なっていることを示している（第 2 図一c)。同時に球晶 中心は秩序が乱されやすい領域であることが指摘され

Vol. 18, No. 213 


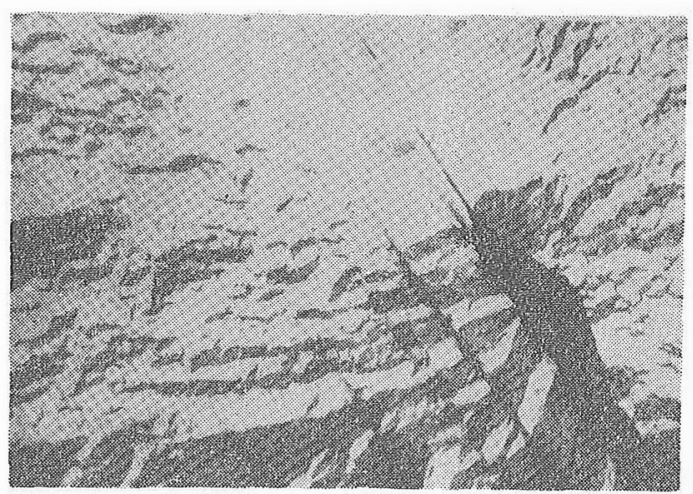

(a)

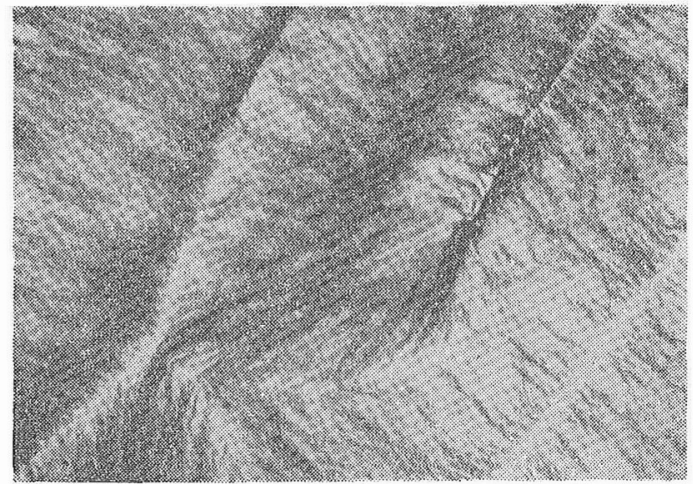

(b)

$た^{6), 12)}$ 。

\section{2-4. 变形した球晶の復元性}

応力下にある均一变形しで球晶は緊張弛緩により变形 前の球晶を復元しようとする。通常一焃に変形した球晶 は復元性が良好で高密度 PE でさえも $10 \%$ 程度の変形 から经㜔完全復元するが，変汧率の橧加とともに復元 性は低下する。この場合緊張弛緩を高温下で行なうか膨 潤下で行ならことにより復元性は増す ${ }^{6), 12)}$

\section{3. 球晶の寸法変化}

上述したように皮膜あるいは成形物つ一糨延伸に伴う 球晶の変形様式は試料の性状掞よび延伸条件によって相 違する。また同一試料中にる異なった変形様式が同時に 観察される。したがって一般には試料のマクロな寸法变 化と球晶の変形倍率は直接には対応がつかない。ここで 試料のマクロな寸法変化と球晶の変形倍率との関婵性が 問題となる。球晶の寸法変化は形態学的な変化をモデル 的に取り扱う場合重要な因子となる。

球晶の寸法変化の検討には光学および電子顕微鏡によ る直接法と光散乱による間接法がある。

木下拈よび馬越は PE の二次元的球晶の一軸延伸に伴 万寸法変化を光学顕微鏡で詳細に検討し球晶中心に近い ほど面積一定の変形で近似され，球晶中心から遠ざかる に従がって体積一定のアフィン変形に近似されることを 示した ${ }^{22}$ 。一方著者らは上と同様光学顕徽鏡により PB-1

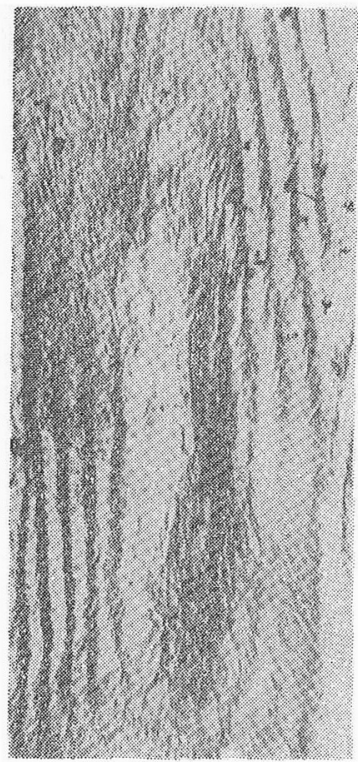

(c)

（a）水面膜 $20^{\circ} \mathrm{C}$ 延佛，（b）水面膜 $95^{\circ} \mathrm{C}$ 延伸, (c) 厚㷬 $95^{\circ} \mathrm{C}$

第 2 図水面膜内球晶敊よび厚膜内球晶の 変形の電子顕微鏡写真, J. Poly. mer Sci., C15, 163 (1966)
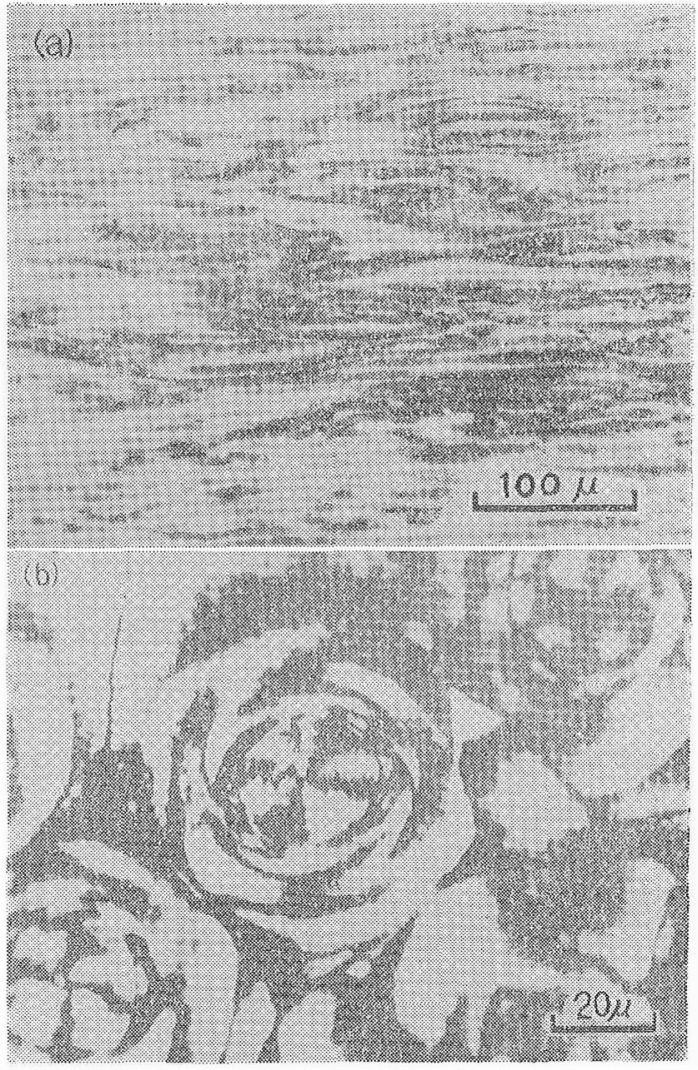

（a）延伸方向に平行な面，（b）延伸方向に垂直な面 第 3 図厚膜内の球晶変形 
(Polybutene-1) の二次元から三次元的にわたる球晶の 一軸楚伸に伴う寸法变化を測定し，個々の球晶の变形率 は皮膜のマクロな延伸率には必ずしも対応しないが, 球 晶の延伸方向の径とそれに垂直な径の比が統計的に二次 元の場合にはアフィン変形から背位するが三次元球晶で は体積一定のアフィン变形で近似できることを示した ${ }^{24)} 。$ ここで体積一定および面積一定の変形は球晶の延伸方向 の径の変形率 $\lambda_{s}$ がそれに垂直な径の变形率 $\lambda_{t}$ および目 視的延伸率(または变形率) $\lambda$ で次式で示される。

$$
\begin{aligned}
& \lambda_{t} / \lambda_{s}=\lambda^{-1 / 2} / \lambda \quad \text { 体積一定 } \\
& \lambda_{t} / \lambda_{B}=\lambda^{-1} / \lambda \quad \text { 面積一定 }
\end{aligned}
$$

また高分子皮膜内の媒体中に狐立して生成した球晶の 变形率は巨視的延伸率に比して小さい24)。

次に三次元球晶の径が小さい（数 $\mu$ 以下）場合には光 散乱法により間接的にその法变化を測定することがで きる。

Stein ら ${ }^{22)}$ および Samuels ${ }^{23)}$ は小角光散乱法により Moore ${ }^{26)}$ は広角执よび小角光散乱法により球晶の寸法 変化が求まることを示した。

第 4 図に低密度 PE 皮膜の延伸に伴ら小角光散乱像の

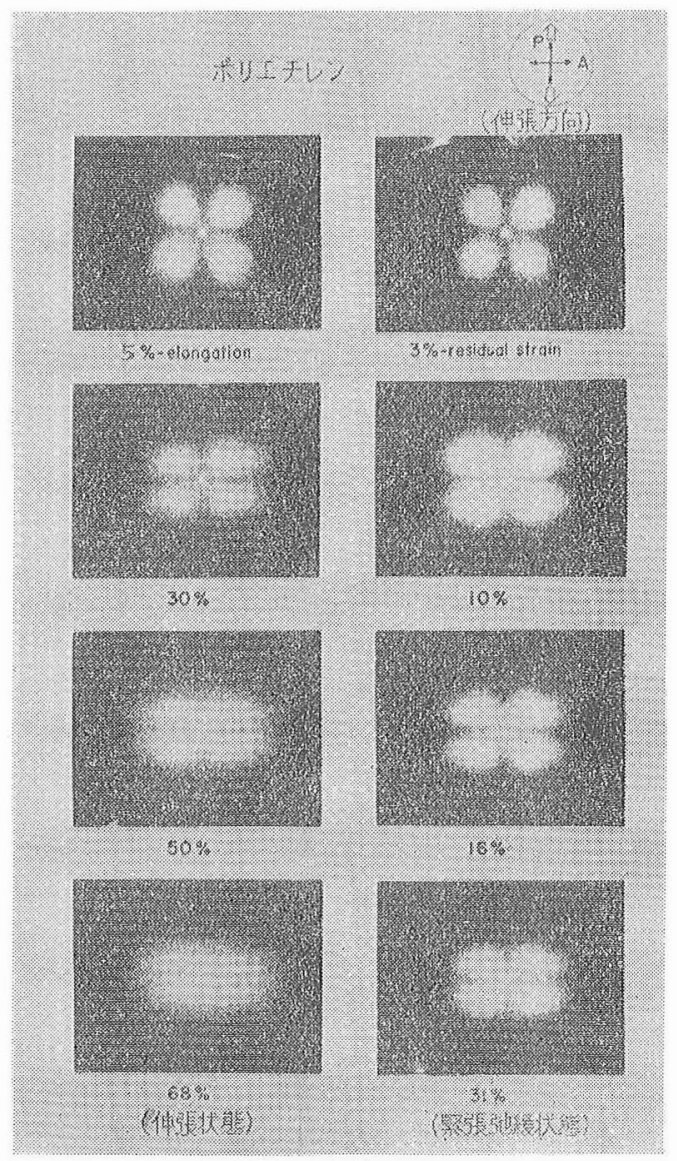

第 4 図 一軸伸張拉よび弾性回復に伴う $H_{v}$ 小 角光散乱像変化 ${ }^{27)}$
変化を示す。四つ葉のクローバの散乱像が延伸率の增加 とともに延伸方向に対し垂直に長くなっていることを示 す。

未変形の球晶からの $H_{v}$ 小角光散乱の散乱強度は Stein らにより (3) 式で与えられる。

$$
\begin{aligned}
I_{H v} & =A V_{0}^{2}\left(3 / U^{3}\right)^{2}\left[\left(\alpha_{t}-\alpha_{r}\right) s_{i}{ }^{2}(\theta / 2) \sin \mu \cos \mu\right. \\
& \times\left(4 \sin U-U \cos U-3 \mathrm{~s}_{\mathbf{i}} U\right)^{2}
\end{aligned}
$$

ここで $V_{0}$ は球晶の体積, $A$ は定数, $\alpha_{t}$ および $\alpha_{r}$ は球晶の半径に垂直および平行方向の分極率， $\theta$ および $\mu$ は入射光に刘する散乱角および検光子偏光面からの 方位角である，また $\mathrm{s}_{\mathrm{i}} U=\int_{0}^{U} \sin x / x d x$ である。

パラメーターUは球晶の半径 $R_{0}$ と次式で関係づけら れる。

$$
U=4 \pi\left(R_{0} / \lambda^{\prime}\right) \sin (\theta / 2)
$$

$\lambda^{\prime}$ は試料中の入射光の波長である。 $U$ は (3) 式に抹 いて $I_{H v}$ が極大をもつよう定めると $U=4.09$ となる。 この值により (4) 式から未変形時の球晶の半径 $R_{0}$ が 求まる。ここで Samuels は変形時の球晶に対して体積 不変を仮定して，小角X線散乱理論を適用することによ り次式を導いた ${ }^{23)}$ 。

$$
\begin{aligned}
U & =4 \pi\left(R_{0} / \lambda\right) \lambda_{s}{ }^{-1 / 2} \sin (\theta / 2) \\
& \times\left[1+\left(\lambda_{s}{ }^{3}-1\right) \cos ^{2}(\theta / 2) \cos ^{2} \mu\right]^{1 / 2}
\end{aligned}
$$

ここで $\lambda_{s}$ は球晶の変形率, $\mu$ は変形時の散乱の方位 角である。Samuels ${ }^{23)}$ は (5) 式より球晶の变形率 $\lambda_{s}, s$ を次式で示した。

$\lambda_{s, s}=\left[\frac{\sin ^{2}\left(\theta_{\max , 1} / 2\right) \sin ^{2} \mu_{1}-\sin ^{2}\left(\theta_{\max , 2} / 2\right) \sin ^{2} \mu_{2}}{\sin ^{2}\left(\theta_{\max , 2} / 2\right) \cos ^{2} \mu_{2}-\sin ^{2}\left(\theta_{\max , 1} / 2\right) \cos ^{2} \mu_{1}}\right]^{1 / 3}$

ここで $\mu_{1}$ および $\mu_{2}$ は任意の二つの方位角であり， $\theta_{\max , 1}$ および $\theta_{\max , 2}$ は $\mu_{1}$ および $\mu_{2}$ での最大散乱 強度を示す角である。

さらに Moore ${ }^{28)}$ は球晶の変形に際して体積変化を考

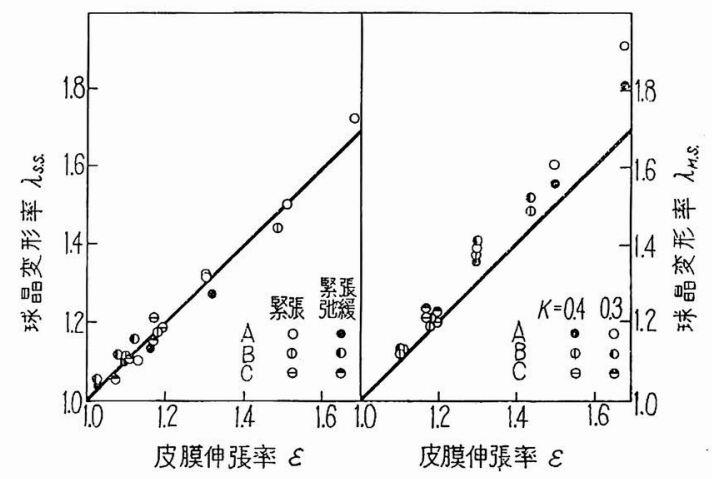

左: Samuels の式による計算, 右: Moore の式による計算

第 5 図一軸伸張および弾性回復に伴ら試料のひ ずみと小角光散乱像より得られた球晶の ひずみとの関係 ${ }^{27)}$ 
慮しポアソン比 $\kappa$ と関連するパラメーター $\beta$ を導入し て, 球晶の変形率 $\lambda_{s}, m$ を示す (7) 式を導いた。

$$
\begin{gathered}
\lambda_{s, m}=\left[\begin{array}{c}
\left\{\sin ^{2}\left(\theta_{\max , 1} / 2\right) \sin ^{2} \mu_{1}\right. \\
\left\{\begin{array}{c}
\sin ^{2}\left(\theta_{\max , 2} / 2\right) \cos ^{2} \mu_{2}{ }^{\prime} \\
-\sin ^{2}\left(\theta_{\max , 1} / 2\right) \cos ^{2} \mu_{1}^{\prime}
\end{array}\right\}
\end{array}\right\}^{1 / 3} \beta^{1 / 3} \\
\beta=\lambda_{t}{ }^{2} \lambda_{s}=\left[(1-2 \kappa) \lambda_{s}+2 \kappa\right]
\end{gathered}
$$

（6）抒よび（7）式により低密度 $\mathrm{PE}$ 皮膜について求 めた結果を第 5 図に示めす。この結果により低密度 $\mathrm{PE}$ については延伸率 $50 \%$ 以内では体積一定としたアフィ ン変形で近似できることが示された ${ }^{27) 。 ~}$

また Samuels はPP 皮膜では体積一定のアフィン变 形で近似されるが PP の Spun fibre ではアフィン変形 に従わないことを示した7)。広角光散乱法により Moore が高密度 PE 皮膜について得た結果执よび小角光散乱 法により Stein らが PB-1 皮膜について, さらに高原 らが PPについて得た結果はいずれもマク口な延伸率に 対し球晶の変形率が小さいことを示している。

以上から三次元球晶については变形染が小さい䉓囲で は体積一定としたアフィン変形により近似されるが，変 形率が大きくなるとマクロな延伸率に比べ球晶の変形率 が小さいことが示され, Hangen らにより光学および電 子顕微鏡観察に执いて示されたよらに球晶間の再配置が 起こることも一昚と考えられる ${ }^{18)}$ 。

\section{4. 結晶性高分子皮膜および成形物の一軸延伸と結 晶および非晶鎖の配向挙動との関連性}

\section{4-1. 一般的な知見}

結晶性高分子固体の延伸に伴ら固体内の微結晶の配向 挙動愎雑で忹あるが，延伸過程と密接な関連にあり， 延伸条件によ。て多少は異なるが結晶分子鎖軸が征伸軸 方向に優先配向し, 分子鎖軸に垂值な結晶軸（単斜晶系， 三斜晶系などについては仮想的な軸）は延伸軸に垂直に 配向するといら普遍性を示す。

結晶性高分子固体は無配向状態において，そのX線回 折像は完全な Debye-Scherer 環を示すが，たとえば一 軸延伸すると結晶各軸の配向は徐々に顕著になり，最終

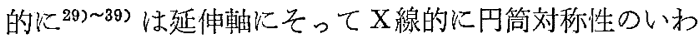
ゆる繊維図形を呈する。その複雑な結晶各軸の配向変化 過程を検討するためには, 結晶各軸の配向度を定量的に 表現する必要がある。

\section{4-2. 結晶配向の定量的な表現}

微結晶各軸の配向の定量的な評価法 ${ }^{40), 41)}$ および数学

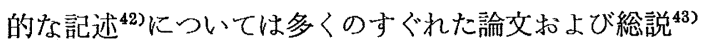
で述べて扣り44，また本稿の主題からもはずれるのでこ こでは省略し，以下にこの小文に用いる配向係数の定義 について簡単に述べる。

いま注目している結晶軸 $\mathrm{c}$ と延伸軸 $Z$ とのなす角を
$\Omega 。$ とすると余弦二乘の平均值 $\left\langle\cos ^{2} \Omega_{c}\right\rangle$ が, 光学量など の物理量あるいは力学量と密接な関係をもっていること から，余弦二乗平均 $\left\langle\cos ^{2} \Omega_{0}\right\rangle$ または〈 $\left.\cos ^{2} \Omega_{c}\right\rangle$ の関 数として配向を表現するのが便利である。ここでは Hermansによって与えられた ${ }^{41}$ 一軸配向係数(配向分布 関数の球面調和関数への展開第二項の係数 $\left.{ }^{80)}\right)$ を用いる。

$$
F_{c}=\frac{3\left\langle\cos ^{2} \Omega_{c}\right\rangle-1}{2}
$$

(Hermans の配向係数)

ここで余弦二乗平均は $\mathrm{X}$ 線回折強度分布から次式で与 えられる。

$$
\left\langle\cos ^{2} \Omega_{c}\right\rangle=\frac{\int_{0}^{2 \pi} \int_{-\pi}^{\pi} I\left(\Omega_{c}, \omega\right) \cos ^{2} \Omega_{c} \sin \Omega_{c} d \Omega_{c} d \omega}{\int_{0}^{2 \pi} \int_{-\pi}^{\pi} I\left(\Omega_{c}, \omega\right) \sin \Omega_{c} d \Omega_{c} d \omega}
$$

$\omega$ は延伸軸に垂淔な面内の方位角であり， $I(\Omega c, \omega)$ は $\mathrm{c}$ 軸の延伸軸に対する配向分布関数である。通常配向分 布関数 $I\left(\Omega_{c}, \omega\right)$ は X線回折強度分布から得ることがで きる。また特定の結晶性高分子については赫外吸収スぺ クトルの 2 色性から〈 $\cos ^{2} \Omega$ 〉を求めることができる。

（9）および (10) 式より結晶軸 $c$ がランダム分布の場 合には

$$
\left\langle\cos ^{2} Q_{c}\right\rangle=1 / 3 \quad F_{c}=0
$$

延伸軸方向に完全に平行な場合には

$$
\left\langle\cos ^{2} \Omega_{c}\right\rangle=1 \quad F_{c}=1
$$

延伸軸方向に完全に垂直な場合には

$$
\left\langle\cos ^{2} \Omega_{c}\right\rangle=0 \quad F_{c}=1 / 2
$$

となる。

結晶各軸の各配向係数の数学的な関係については Wilchinsky 拉よび Sackにより詳細に得られており ${ }^{42)}$, さらにより一般的な記述が河合によって与えられてい る ${ }^{80)}$ 。たとえば三主軸 $\left(c_{1}, c_{2}\right.$ および $\left.c_{3}\right)$ が直交する場 合次式となる。

$$
F_{c 1}+F_{c 2}+F_{c 3}=0
$$

\section{4-3. 非晶鎖の配向評価}

非晶鎖の配向評価は複属折法, 赤外二色法, 可視执よ びケイ光染色二色法, $\mathrm{X}$ 線散乱その他により行なわれ

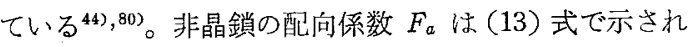
る。

$$
F_{a}=\frac{3<\cos ^{2} \Omega_{a}>-1}{2}
$$

Sa は非晶鎖軸と延伸軸とのなす角である。ここでた とえば赤外二色法に抢いては非晶性バンドの二色比 $\left(D_{a}\right)$ は配向係数 $F_{a}$ と（14）式で関連ずけられる。

$$
\left(D_{a}\right) \equiv \frac{\left(A_{a}^{0}\right)_{\perp}}{\left(A_{a}^{0}\right)_{/ /}}=\frac{1-F_{a}}{2 F_{a}+1}
$$

$\left(A_{a}{ }^{0}\right)_{\|}$および $\left(A_{a}{ }^{0}\right)_{\perp}$ は非晶性バンドの延伸方向に平 行および垂直方向の積分吸光度を示す。

いま複屈折の測定から, 非晶相の複屈折 $\Delta a$ が得ら 
れる場合は (15) 式により非晶鎖の配向係数 $F_{a}$ が算出 できる。

$$
\Delta_{a}=\frac{2}{9} \pi \frac{\left(n^{2}+2\right)^{2}}{n} N_{a}\left(\alpha_{11}-\alpha_{\perp}\right)_{a} \cdot F_{a}
$$

ここで $n$ は平均屈折率， $N_{a}$ は単位体積あたりの非晶 鎖の単位ユニットの数， $\alpha_{\| \prime}$ 打よび $\alpha_{\perp}$ はそれぞれ分子 鎖に平行㧍よび垂直な方向の分極率である。

\section{4-4. 一軸延伸過程と結晶配向挙動 ${ }^{22}$, 45)}

ここで現在まで最も実験例の多いポリェチレンを例に とり, 一軸延伸に伴う結晶配向挙動が応力ーひずみ曲線 と密接な関連性をもつことを示をう。

第 6 図に溶融状態から作成した比校的 厚い（約 0.3 $\mathrm{mm}$ 厚) 低密度 PE 皮膜の応力-ひずみ曲線およびひず 又一非弾性度曲線を示す。この皮膜はX線的に微結晶がラ

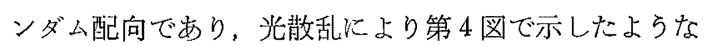
球晶特有の四つ葉クローバ状の光散乱線を与兄る。第 6 図の応力ーひずみ曲線において最初の矢印は降伏点を，

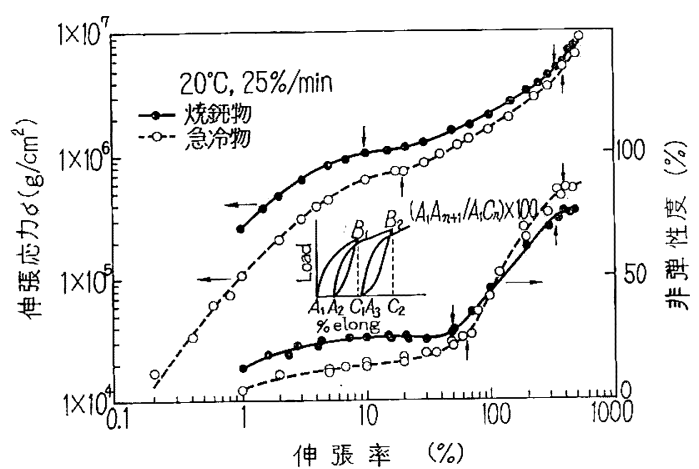

第 6 図低密度ポリェチレンの応力ーひずみ曲線虍よ びひずみ-非弾性度曲線, Proc. 4th Intern. Cong. Rheo., Interscience, New York, Part 3, 501 (1965)
後の矢印はネッキングの 終了点を示す。またひずみー非 弾性度曲線の初めの矢印が巨視的なネッキングの発生点 に相当し、ネッキングの発生点までは皮膜は巨視的に一 様泟伸される。

次に第 6 図の延伸過程で特徵的な变化を示す延伸率に 緊張のまま固定および固定後緊張弛緩した試料の結晶各 軸の配向変化を第 7 図に示す。第 6 図と第 7 図との対比 から各延伸領域の区分拉よびその特徵が明確となるであ ろう。

i）降伏点までの領域結晶 $\mathrm{c}$ 軸が延伸方向に, 結 晶軸 $\mathrm{a}$ は延伸方向に垂直に配向し, 結晶b軸はほとど配 向を示していない。また緊張弛緩後結晶各軸の配向は注 とんぞ完全に回復する。

ii） ネッキング発生までの領域 延伸率の增加とと も結晶 $\mathrm{b}$ 軸が延伸方向飞垂直に配向の増加を示す。ま た延伸率の増加ととすに結晶 $\mathrm{a}$ 扣よび $\mathrm{c}$ 軸は緊張弛緩後 に配向の非回復性の增加が見られる。一方結晶 $\mathrm{b}$ 軸が緊 張弛緩後に延伸方向への正の配向回復性をとることを示 している。

iii）ネッキングの領域 結晶 $\mathrm{b}$ 抢よび $\mathrm{c}$ 軸の配向 が顕著となる。また緊張弛緩後の結晶各軸の配向の非回 復性が著しく增加する。

iv）ネッキング完了後の領域延伸率の增加に伴 ら配向および緊張驰緩後の結晶各軕の配向の変化がきわ めて小さいことを示す。

i）および ii）の領域怔常巨視的に一様佂伸され る。この領域については次節で詳述する。iii）の領域は 小角および広角 $\mathrm{X}$ 線回折, 電子顕微鏡により詳細に検討 されて抢り22,46)，またiv）の領域についてもその弾性 および塑性機構など興味深い検討が行なわれているが紙 面の都合で交献の及示す48),76)。

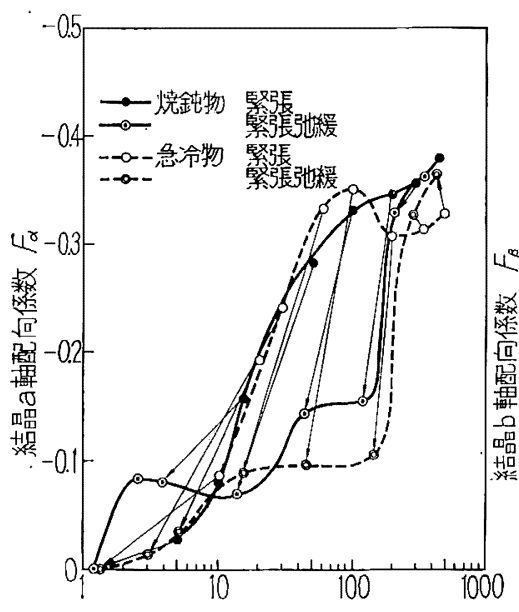

伸 張 率

(a)

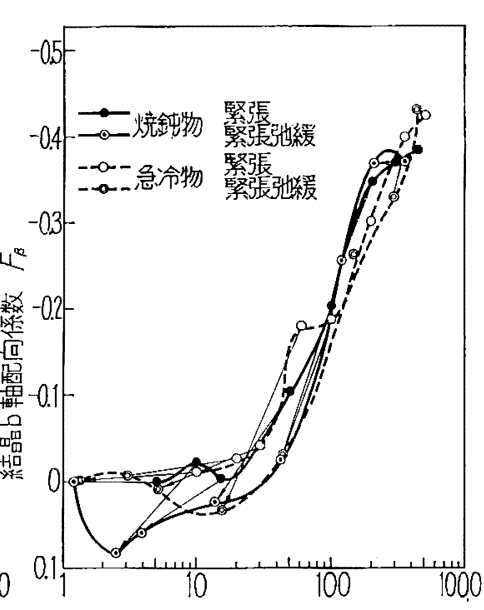

伸張率 (\%)

(b)

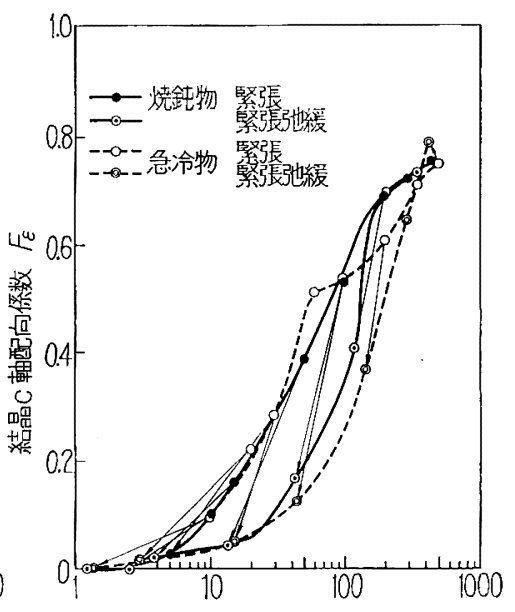

伸張率 $(\%)$

(c)

第 7 図 低密度ポリエチレンの一軸延伸および緊張の弛緩に伴う結晶各軸の配向挙動 45 )

Vol. 18, No. 213 


\section{4-5. ネッキング発生までの領域における種々の結晶 性高分子固体の配向举動}

上述の i）および ii）のネッキング発生までの領域に おいて結晶分子鎖軸（c 軸）に対し垂直な結晶 a 扣よび $\mathrm{b}$ 軸は著しく異なった配向挙動を示し，常に結晶 $\mathrm{a}$ 軸が 結晶 $\mathrm{b}$ 軸より優先負配向を示している。さらに結晶 $\mathrm{b}$ 軸 の延伸初期の配向係数が小さなこと，招よび緊張弛緩後 に配向係数が負から正へと変化することは少なくとも二 つの配向機構すなわち延伸方向に平行拈よび垂直な配向 を示す機蔧が同時に存在することを暗示するであるら。

Sasaguri らに上る PP 皮膜の一朝延伸に伴う複屈折変 化も同様の暗示を与えている。

ここで他の結晶性高分子固体の結晶各軸の配向挙動を 整理検討する。上に示したような低密度 PE ばかりでな く, 第 8 図に示すように高密度 $\mathrm{PE}, i s o-\mathrm{PP}^{49,503}$ 拈よび PB-133) のように比較的結晶性が高く，しかも明らかに 結晶高次組織（球晶）を形成している場合には，結晶分 子鎖軸 ( $\mathrm{c}$ 軸) が盗伸方向に優先配向するのは变わりな いが結晶分子鎖軸に垂直な二軸はかなり相違する配向挙 動を示すことが特徵的である。しかも結晶分子鎖軸住垂 直な二軸のらち球晶内で半径方向となっている結晶軸 (PE および PB-1 では結晶 $\mathrm{b}$ 軸, PP では結晶 $\mathrm{a}^{*}$ 軸) は，他の軸（PE および PB-1 では結晶 $\mathrm{a}$ 軸，PP では 結晶b軸）の配向に比べて扮くれる傾向にあり，これは 球晶を形成する結晶ラメラの形および結晶ラメラ軸方向 の構成徽結晶の相互作用の強さから説明されよう。

一方比較的結晶性の低い膨潤した isotactic, atactic

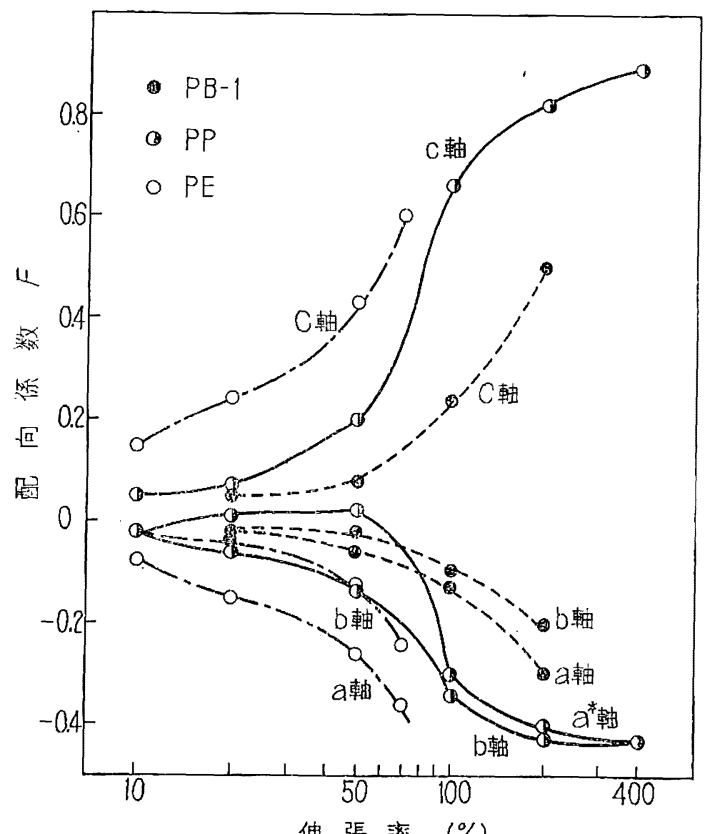

伸張率 (\%)

第 8 図種々の Poly-olefine の結昆各軸の 配向挙動

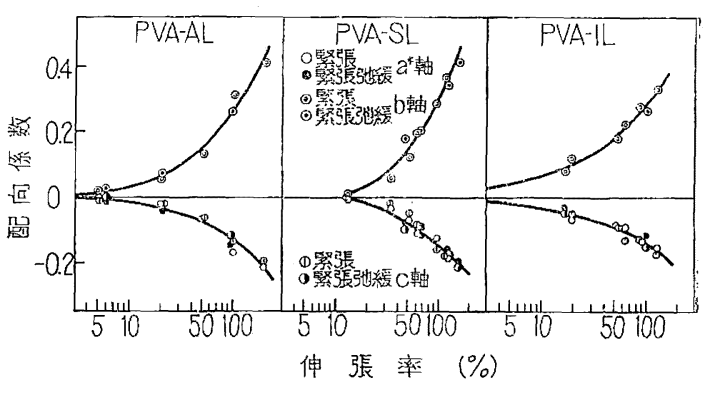

第 9 図 PVA の一軸佂伸に伴亏結晶配向举動, $J$. Polymer Sci., 4, A-2, 797 (1966)

および syndiotactic PVA の配向挙動は第 9 図に示す 上うに結晶分子鎖軸（PVA で结結晶 b 軸）の延伸軸方 向への優先配向は上と同じであるが，結晶分子鎖䩜に垂 直な二軸は延伸軸に同じ配向挙動を示す。しかも上の球 晶を形成している場合と比べて結晶分子鎖軸の配向は著 しく低下している51。 atac- $\mathrm{PP}^{52)}$, iso-PVC ${ }^{53)}$, エチレ ンープロピレンランダム共重合体 $(\mathrm{EPRC})^{88}$ 打よびiso$\mathrm{Pst}^{54)}$ でも同様の結果が得られている。上記三種の PVA の比洨的低延伸率の結晶配向挙動は Kratkyによる第一 変形機構 (floating rod model) $)^{55}$ によりよく説明され る。結晶性が低い場合結晶ラメラの分布が蹯で延伸漈 して結晶ラメラ間の相互作用性がきわめて低く Kratky の第一変形機靴に従うものと考克られる。結晶性が 高 くなり結晶ラメラの分布が密沈なると結晶高次組織の形 成のため, 未変形時の結晶ラメラの形およびその特殊な 配列が变形に際して結晶ラメラ間の相互作用性（たと兄 ばラメラ間拈よびラメラ内結晶面間のすべり変形など) が增加するものと考学られる。

iso-PP から atac-PP までのように広範囲に結晶性の 異なる試料が得られる場合結晶高次組織との関連におい て配向挙動を娭討することは興味深い52)。

\section{4-6. 諸環境条件下での結晶の配向および配向回復挙 動}

結晶高次組織が形成されている場合，複䧴な渔向挙動 を示すことはすでに述べたが配向挙動と内部の変形機構 との関連性すなわち变形の主役が何かをより詳細に検討 する必要がある。ここでは低密度 $\mathrm{PE}$ を例にとり二三の 環境条件下に淤方結晶各軸の配向挙動への影響を検討 乙可能な変形機構を推察する。

\section{4-6-1. 種々の延伸温度における結晶配向挙動 ${ }^{562 \sim 58)}$}

第 10 図に高密度 PE の延伸温度が異なる場合の配向 挙動を示す。結晶 $\mathrm{a}$ 学よび $\mathrm{c}$ 軸の配向性は延伸温度の上 昇とともに低下している。さらに異なった延伸温度に対 する緊張拈よび緊張弛緩に伴う配向のヒステリシスには 著しい差異が認められる。これは第 9 図に示されるPVA の配向挙動がヒステリシスを示さないことと対比されよ 


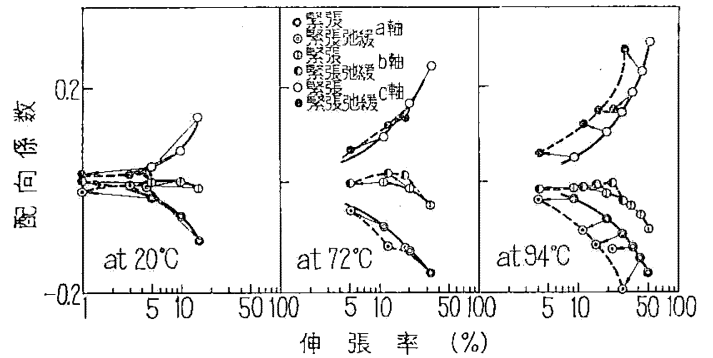

第 10 図高密度ポリエチレンの種々の温度での一軸 延伸に伴ら結晶配向挙動和上び弾性回復に 伴亏配向回復挙動
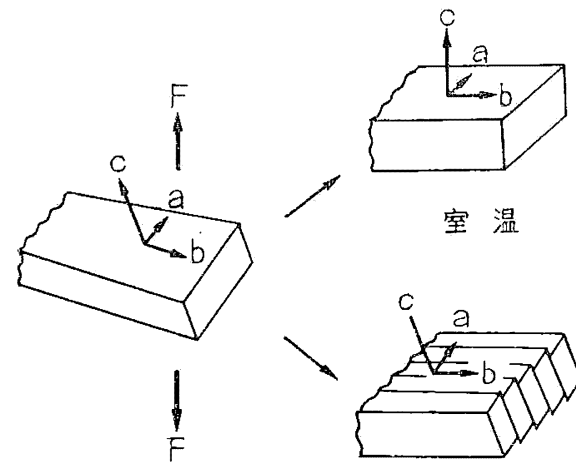

室 温

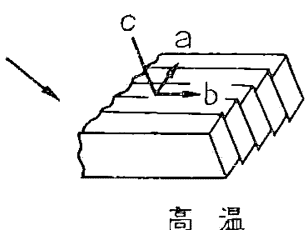

第 11 図結晶ラメラ暎委わりの結㫛ラメラの回鞋 を伴う変形機構 ${ }^{56)}$, (100) 面にそった塑 性すべり

う。延伸温度の上昇とともにたと光ば結晶 $\mathrm{c}$ 軸の配向と ステリシスは時計なわりから反時計まわりと変化してい る。この絬果は低密度 PE およびiso-PPについても伍 とえぞ同じ傾向を示す。

延伸温度の上昇は結晶ラメラ内に格子不整を多くする 効果就よび非晶鎖の分子運動性の増大する効果が考古ら れる。したがって結晶ラメラ間扣よびラメラ内のすべり に上る塑性变形が起こりやすくなるととるに非晶鎖のか らみあいといった弾性機構が消失していくことが推察さ れる。しかしながら PE 抢よび PP の配向性に対する 延伸温度の影響は，PE では結晶 $\mathrm{a}$ 軸の PP では結晶b 軸の䓡膨㖘係数が增大する一種の特性温度 ${ }^{593}$ 以上で著し い。したがってたと党ば PEについては延伸温度の上昇 により特に結晶 (100) 面あるいは結晶 $\mathrm{a}$ 軸にそった一 種の不整格子領域でのすべり変形が起こりやすくなると 考光るのが合理的であろう。第 11 因に模式的に示す。

\section{4-6-2. 膨潤下での配向挙動 ${ }^{60), 61)}$}

第 12 図に低密度拈よび高密度 $\mathrm{PE}$ をキンレン中で延 伸した際の試料の配向挙動を示す。結晶 $\mathrm{a}$ および $\mathrm{c}$ 軸の 配向性の低下が著しく結晶 $\mathrm{a}$ 打よびの b 軸の配向挙動が ほとんど同じになることは顕著な特徵である。これは第 9 図の膨㵎のPVA配向挙動と酷似している。

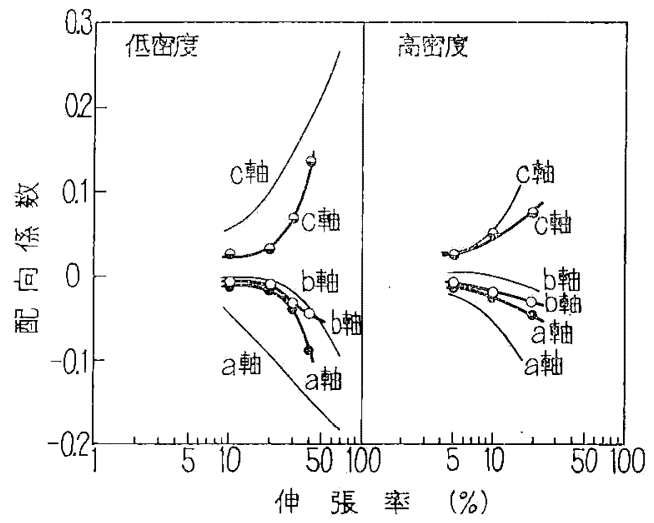

第 12 図低密度㧍よび高密度ポリェチレンの膨潤

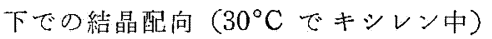
太線：澎潤，細線：漧燥

Ratt $^{89)}$ らによれば PE の場合膨潤の効果は通常結晶 格子には影響しないと考えられ，非晶鎖のからみあいが とけやすくなる效果が考它られよう。しかしながら結晶 a および b軸が同じ配向挙動を示すことから膨潤により 結晶 $\mathrm{a}$ および $\mathrm{b}$ 軸が結晶分子鎖に対し同等の变形性をも たねばならない。したがって膨閏した場合延伸に対して 結晶ラメラ単位の変形よりも, 結晶ラメラ内でたと光ば モザイクブロック的な単位 ${ }^{90)}$ の変形が起こりやすくなる と考学るのが妥当と思われる。

\section{4-7. 非晶鎖の配向挙動 ${ }^{6), 517,60), 61) ~}$}

第 13 図 (a) および (b) に低密度PE抽よび PVAの 非晶鎖の配向挙動を示す。PVA の結晶分子鎖軸（b軸） の配向挙動（第 9 図）壳非晶鎖の配向挙動とは少なくと も低延伸領域ではほとんど同じであることを示してい る。一方 PE では結晶 $\mathrm{c}$ 軸の配向係数に比べ非晶鎖の 配向係数は同じ傾向ではあるがかなり低いことを示して いる。さらに中密度执よび高密度 PE 特よび iso-PP で は延伸初期注いてわずか比延伸方向に垂直な負の配向 性を示すことが報告されている。これらは結晶性が低い 場合結晶の配向が非晶鎖によって支配される総状ミセル 型の機構により説明され，結晶性の増大とともに結晶ラ メラ間和よびラメラ内のすべりを伴ら変形の笴与が增大 することを示するのであろう。

一方非晶鎖は弾性機構の主役を演じていると考えられ る。したがって残留ひがみをるつ試料が高温下には膨潤 下で復元性を增加することは非晶鎖の分子運動性の增加 と密接に関連し, 結晶性が高い汪ど復元性は低下寸る。 非晶鎖の役割は試料皮膜㕜電子線照射することによりよ り明らかとなる。照射量の堌加とともに結晶 $\mathrm{c}$ 軸の配问 が增加するとともに，膨潤による結晶各軸の配向性の低 下は減少する ${ }^{88)}$ 。これらの一連の現象は電子線照射によ り結晶ラメラ間の連結鎖の增加および結晶内分子鎖の橋 かけを考兑ることによりよく説明される ${ }^{91}$ 。 


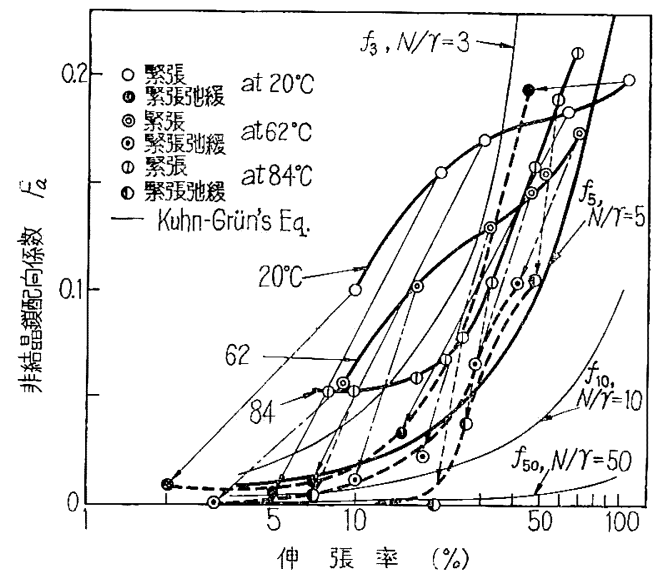

(a)

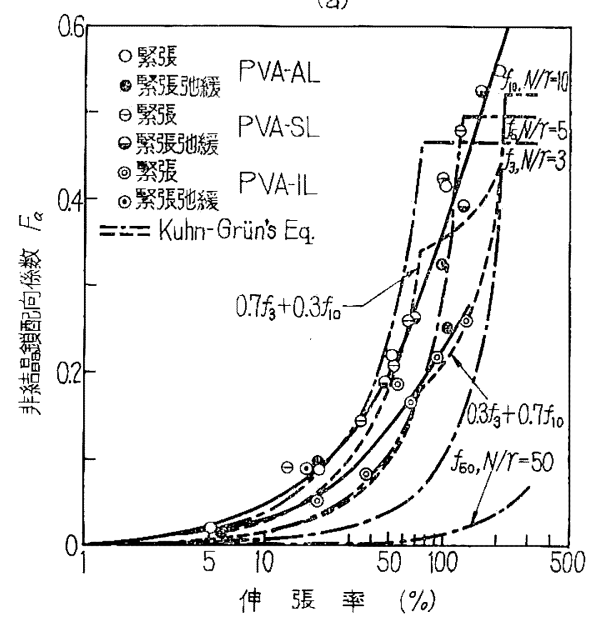

(b)

(a) 低密度ポリエチレン，（b） ポリビニルアルコール

第 13 図非晶鎖の配问挙動 $(N / r$ は分子長と末 端間距離との比を表方す)

\section{5. 延伸に伴う長周期の变化および配向}

結晶性高分子固体からの小角X線回折強度分布掞よび 最大強度位置は延伸に伴い变化する。小角X線回折が皮 膜あるいは成形物中の長周期（結晶ラメラの厚みの中心 から次の結晶ラメラの中心をで）を与えるとすると，小 角X線回折強度の極大を与之る回折角から長周期を, 積 分回折強度の方位角方向分布から長周期を与古る回折面 の配向分布がわかる。

長周期の变化については PE，PP(2) 64)，Nylon 66 などについて検討が行なわれており，たとえば高延伸皮 膜を伸張方向に平行に伸張すると伸張方向に平行な側で 湿著に増加し，伸張方向に垂直な側で変化しないか減少 することが明らかにされている。

一方, 長周期の配向分布之結晶分子鎖軸の配向分布之 の関連性は PE について複雑であるが一定の規則をひ

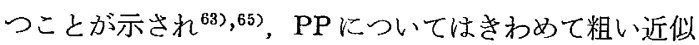

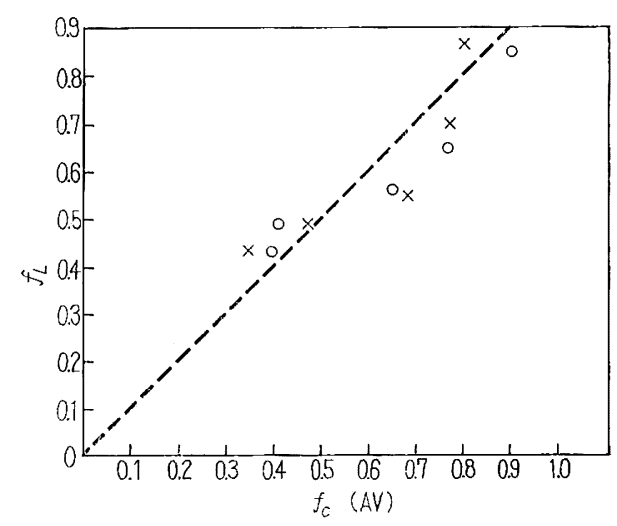

第 14 図結晶 $\mathrm{c}$ 軸の配向と長周期の配向々の関係, J. Polymer Sci., 6, A-2, 1101 (1968)

ではあるが第 14 図に示すよらに䩦い相関性を示す結果 が得られている7。

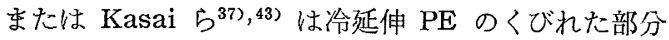
での広角および小危X線像を詳細に検討し微結晶の大き さはくびれた領域に入るまでに崩解して小さくなること を示した。

以上から延伸した際にネッキングの発生までの領域で は微結晶はほとんぞ崩解ぜず，結晶ラメラ面の法線が延 伸方向と平行になっている結晶ラメラ間の変形の大きい ことが推察される。

\section{6. 延伸に伴う球晶内の局所的な配向変化}

延伸に伴う球晶の外形変化と平均的な配向挙動とが関 連つけれるためには, 延伸に伴ら球晶内の局所的な配 向变化を知ることが必要である。通常球晶内の局所的な 構造変化の観测はきわめて困難であるが， PE，iso-PP， PB-1 のように比較的大きな二次元球晶が得られる場合 には, 延伸に伴う球晶内の局所的な配向变化をマイクロビ 一ム X線回折, 顕微複屈折あるいは赤外線吸収により湘 定が可能である。Hay-Keller ${ }^{6)}$ は PE 球晶の局所的な $\mathrm{X}$

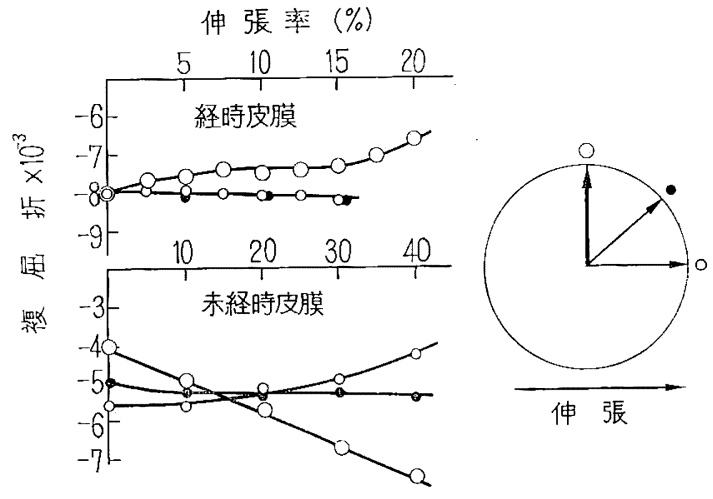

第 15 図球晶内局所的な複屈折变化, $J . A p p l$. Phys., 35, 47 (1964) 
線回折変化を, Stein らは, PB-1 球晶 ${ }^{66), 67) の, ~ S a m u e l s ~}$ は iso-PP ${ }^{7}$ 球晶の局所的な複屈折変化を先れぞれ測定 している。第 15 図は Sasaguri-Steinによる PB-1 の複 屈折の結果 ${ }^{67)}$ 示すが，延伸軸住対して垂直方向が最も 変化しやすく， $45^{\circ}$ 方向が最も変化しにくいことを示し ている。これらの結果は球晶变形に和いて延伸軸汇垂直 な方向の結晶ラメラ軸委わりの微結晶の回転を伴ら変形 機構が起こりやすく，45方向では結晶ラメラ間のすべ りなど結晶配向の変化が少ない変形機構が起こっている ことを示唆すると考兄られ，PE などに詨するX線回折 像呩よび顕微鏡写真ともよく対応している。

\section{7. 結晶ラメラ内の基本的な変形機構}

\section{7-1. 単結晶の延伸}

結晶性高分子固体の延伸（あるいは球晶の変形）飞伴 ら分子配向挙動を理解するためには, 結晶ラメラ間の変 形の他に結晶ラメラ内の変形が明らかにされねばならな い。ここ数年 Geil-Peterlin-Kiho は高分子単結晶を補

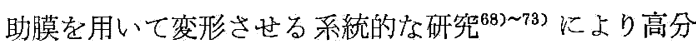
子結晶の基本的な变形機構を明らかにしている。これら の変形機構は皮膜あるいは成形物の変形には直接あては めるわけにはいかないが基本的な变形機構として次の機 構が示されている。

i phase transformation (相転換)

(第 16 図 $\quad$ b ) $)^{\text {70) 79) }}$

ii twinning (双晶化)

(第 16 図 C $)^{70), 71), 78), 799}$

iii tilting (分子鎖傾斜)

(a)

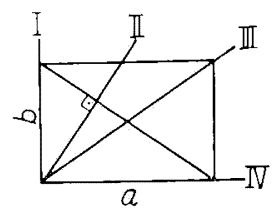

(b)
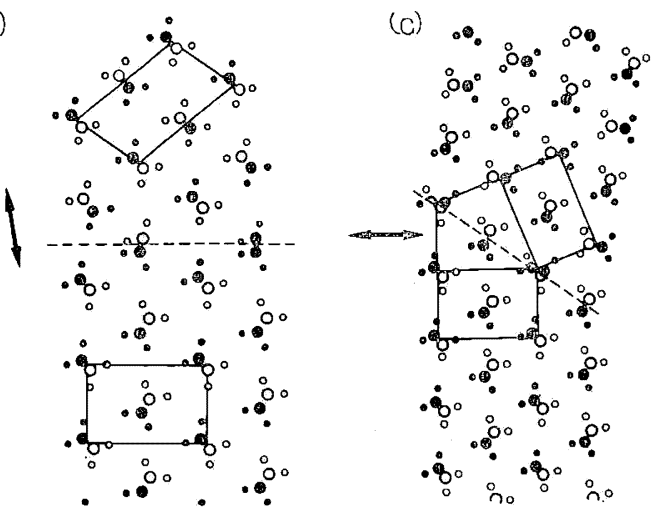

第 16 図 (b) phase transformation, 拉よび (c) twinning, J. Polymer Sci., C9, 61 (1969)

Vo1. 18, No. 213
(第 17 図 $\quad$ a ) ${ }^{68), 7475)}$

iv cracking and fibering

(第 17 図b拈よびc $)^{72,74), 75)}$

単結晶板の延伸方向および延伸温度により各変形機構 の組合せが相違するとともに，同じ变形機構でも結果と して表われる方位が異なることが明らかにされている

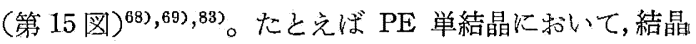
a 軸に添涪平行以延伸される場合 $100 \%$ 以上の延伸が crack が生じることなく可能であり，結晶ラメラ内での chain tilting が主として起こると考兄られる（第17 図 a 特よび第 18 因a)。また結晶 $\mathrm{b}$ 軸に注济平行に延伸 されると twinning はなく, phase transformation が 主として起こり（第 16 図b就よび第 18 図b）他の軸 は twinning および phase transformation が同時に 起こることを示す。

7-2. 皮膜あるいは成形物の変形機構と単結晶の変形 機構との関連性

皮膜あるいは成形物の変形に際して内部の変形機構と して, 結晶ラメラ単位の変形機構と結晶ラメラ内の変形 機構が存在するであろうことは先に述べた。

上の変形機構を検討してみるとまず phase transformation については PP 拉よび PB-1 の一軸延伸に おいて見られるように延伸率の增加とともに高温で安定 な結晶型から低温で安定な結晶型への变換が起こってい る50。しかしながらその逆の phase transformation, たとえば PE の orthorhombic から monoclinic への

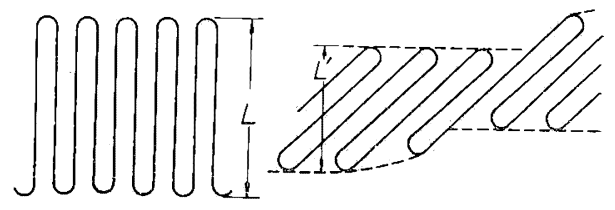

(a)

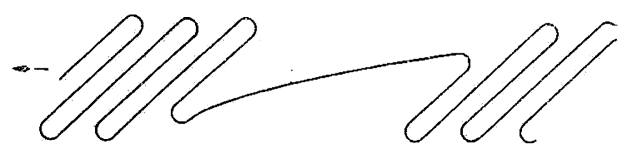

(b)

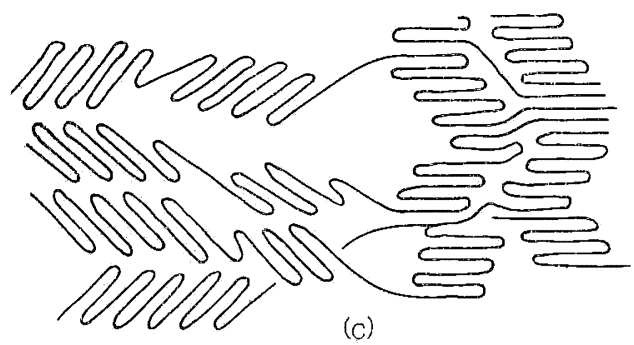

第 17 図 (a) chain tilting, (b) cracking, 特上 び (c) fibering, J. Polymer Sci., C15, 427 (1966) 


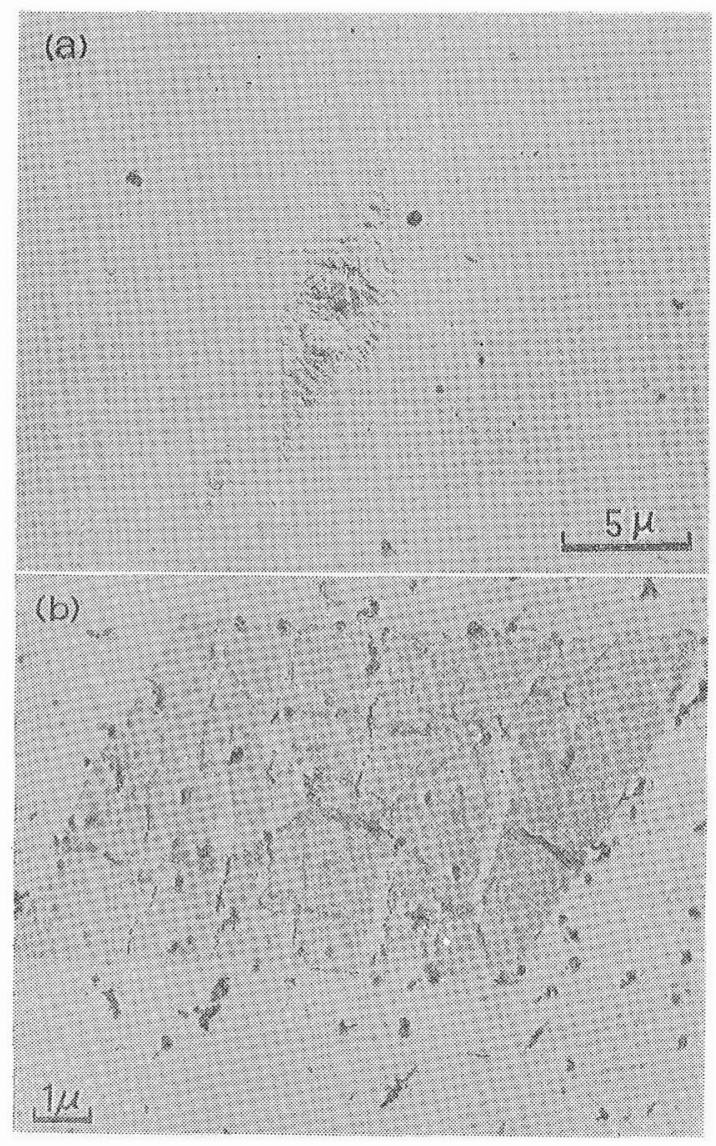

第 18 図単結晶の延伸 (a) a 軸に平行, (b) b 軸に平行 (Geil 著 Polymer Single Crystals, Interscience, New York (1963))

phase transitionは圧縮あるいは補助膜をつかっての変 形に持いて現われやすい、14),703,76),77)ように結晶格子を多 軸的な応力下に拉くことが必要であると考えられる。 twinning は結晶ラメラ内変形の中で最す配向に効果的 な峦形機構であろら。また Peterlin によって指摘され ている74) ように $10 \%$ 程度の伸張が説明可能である。し かしながら配向物に打いては瀬戸ら扣よび伊藤らによっ て検討されているように検出されるが767,77)，無配向物 そついては他の機構による配向との区別がつかず検出し にくい。いずれにしても $100 \%$ 前後に及ぶ変形には有効 とは思われない。したがって前述したように tilting 拉 よび cracking は非結晶鎖の伸張とともに大変形を行な うために重要な変形であろう。

\section{8. 球晶内の結晶配向と変形構機6)}

PE 球晶について考察する。未変形状態において延伸 軸方向に対して結晶ラメラ軸の方位は平行から垂直まで 順次変化する。上に述べたように結晶ラメラの变形には 強い方向依存性がある。したがって延伸軸とのなす方位

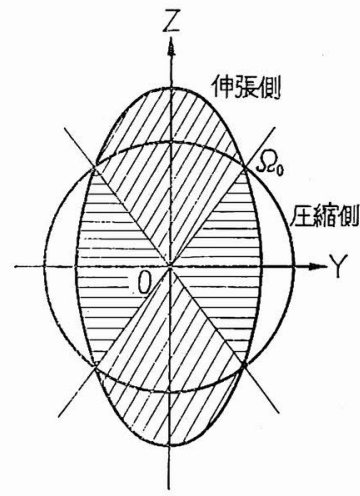

第 19 図球晶变形に打ける延伸領域 圧縮領域

を第 19 図のように大きく分けて検討する。

\section{8-1. 延伸方向に平行なラメラの変形}

結晶 $\mathrm{c}$ 軸は常に延伸軸に対して垂直であり，結晶 $\mathrm{c}$ 軸 が延伸方向へ配向するためには結晶 $\mathrm{a}$ 軸まわりの結晶 $\mathrm{b}$ 扣よび $\mathrm{c}$ 軸の回転を含む変形が起こらねばならない。こ の条件に適合する变形機構として次のものが考えられよ ら。

i 結晶ラメラの cracking を伴う結晶a軸まわりの 回転

ii 折りたたみ結晶の繊維状結晶への転換

iii 結晶 b 軸がやや傾いた場合は（010）または(110) 面の [001] 方向へのすべり変形

\section{8-2. 延伸方向に垂直な結晶ラメラの変形}

結晶ラメラのねじれ生長によって結晶b軸まわりに結 晶 $\mathrm{a}$ 㧊よび $\mathrm{c}$ 軸が回転して存在する。したがって結晶 $\mathrm{c}$ 軸が延伸方向にある場合は特別な変形は起こらないであ ろう。結晶 $\mathrm{c}$ 軸が延伸軸から傾いている場合には, 結晶 $\mathrm{b}$ 軸まわりの結晶 $\mathrm{a}$ および $\mathrm{c}$ 軸の回転を含む変形がある。

i 結晶b軸まわりの結晶ラメラの回転ねじれ

ii（100）または（110）面の [001] 万向へのすべり

iii (001) 面の [100] 万向の結晶ラメラ間のすべり

\section{8-3. 他の方向の結晶ラメラの変形}

8-1. および 8-2. で述べた変形の他に $45^{\circ}$ 方位に近 づくに従って (001) 面の〔010] 方向の結晶ラメラ間す ベりが大きく笴与すると考えられる。

結晶ラメラ間のすべり変形は結晶ラメラの構造および tie chain の密度に大きく依存するであろう。特に $45^{\circ}$ 方位方向は結晶ラメラ間のすべり応力が大きい。したが って Keller ${ }^{6)}$ および Peterlin ${ }^{75)}$ によって指適されるよ らに球晶の变形が起こりやすいことが考えられる。しか しなから Kobayashi-Nagasawa ${ }^{13)}$, Hay-Keller ${ }^{6)}$ 执よ び Geil ${ }^{8)}$ の球晶变形の電子顕微鏡写真からは $45^{\circ}$ 方向 の変形が必ずしも優先的な变形とは考兄られないが，延 伸軸方向の円推側と延伸軸に垂直方向の円推側で $45^{\circ}$ に 
近い角度で変形機構を異にすることが推察される。

\section{9. 球晶变形のモデル的考察}

結晶性高分子の物理的, 力学的性質を構造と結びつけ 解釈するためには，先に述べた形態学的な变化新よび微 結晶执よび非晶鎖の配向变化を定量的に表現することが 必要である。このよらな目的は球晶変形をモデル的に表 現し微結晶および非晶鎖の配向変化と此較することによ り得られるであるら。最近ではX線回折によって得られ る結晶各軸の延伸軸に対する配向分布と球晶変形モデル から予想される配向分布とを直接比較する試みもなされ

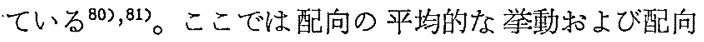
分布と球晶变形のモデル的表現により予想される配向変 化との比較を行なう。

\section{9-1. アフィン変形}

媒体の巨視的变形に伴ら媒体归の何らかの眍向単位の 配向挙動を記述するには，従来のゴム弾性論に扣ける試 料の巨視的変形に際して構造単位のミクロな変形表現に 用いられたいわゆる比例定理の手法 ${ }^{82)}$ を用いることが数 学的表現の単純化をはかるために便利であるら。一方球 晶の変形に際しての寸法変化に拈いて示したように少な くとも比較的変形率の小さい領域で球晶の外形の变化に 対してはアフィン変形を適用するのがよい近似である 万。

いま，煤体中以直交座標（X, Y, Z）を第 20 図のよ らにとり，媒体が $\mathrm{X} ， \mathrm{Y}$ および $Z$ 方向にそれぞれ $\lambda_{1}$,

$\lambda_{2}$ ，および $\lambda_{3}$ 倍の変形を受たとき，未変形時の単位体 積の媒体中にランダムに存在した $N$ 個の配向単位のう ち，角 $\Omega$ および $\omega$ 方向の単位立体角中に存在する配向 単位の数 $N(\Omega, \omega)$ は Sasaguri らにより (16) 式の ように与えられた。

$$
\begin{aligned}
N(\Omega, \omega)=\frac{N\left(\lambda_{1} \lambda_{2} \lambda_{3}\right)^{2}}{4 \pi\left[\lambda_{1}{ }^{2} \lambda_{2}{ }^{2} \cos ^{2} \Omega_{\lambda}+\lambda_{3}{ }^{2} \sin ^{2} \Omega_{\lambda}\right.} \\
\left.\times\left(\lambda_{2}{ }^{2} \cos ^{2} \omega_{\lambda}+\lambda_{1}{ }^{2} \sin ^{2} \omega_{\lambda}\right)\right]^{3 / 2}
\end{aligned}
$$

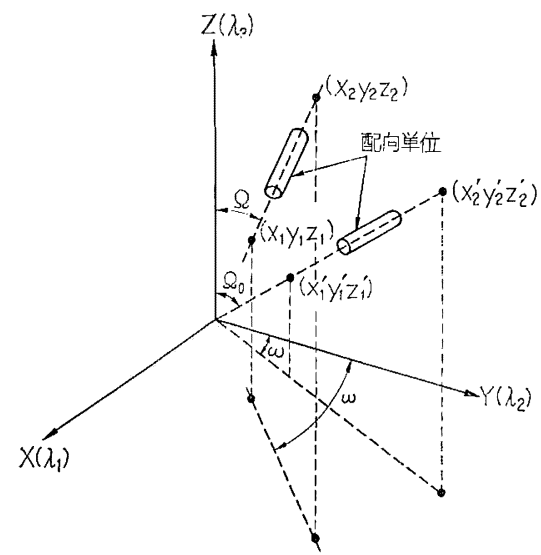

第 20 図 座禋系と配向単位に対する角度
（16）式は全く任意の変形様式を示している。

9-2. 理想一軸変形および理想シート変形

（16）式に扣いてたと党ば PE について䍐向単位を 微結晶にとり配向軸を結晶 $\mathrm{c}$ 軸とすることができる。 Wilchinsky はこのようなモデルにより変形に際して体 積一定を仮定して理想一軸変形拉よび理想シート変形 (strip-biaxial) について計算を行なっている。変形に 際して体積一定を仮定すると（16）式にそれぞれ次の条 件を代入することによって配向単位の分布関数 $N(\Omega, \omega)$ が計算可能である。

理想一軸変形

$$
\lambda_{1} \lambda_{2} \lambda_{3}=1, \quad \lambda_{1}=\lambda_{2}=\lambda^{-1 / 2}, \quad \lambda_{3}=\lambda
$$

理想シート変形

$$
\lambda_{1} \lambda_{2} \lambda_{3}=1, \quad \lambda_{1}=\lambda^{-1}, \quad \lambda_{2}=1, \quad \lambda_{3}=\lambda
$$

同時二軸変形

$$
\lambda_{1} \lambda_{2} \lambda_{3}=1, \quad \lambda_{1}=\lambda_{2}=\lambda, \quad \lambda_{3}=\lambda^{-2}
$$

ここで理想一軸変形についてさらに一般化するために Moore は（8)式に示したパラメーター $\beta^{\prime}$ を導入した。 以下一軸変形についてのみ示す。

$$
\begin{aligned}
& \beta^{\prime}=\lambda_{1}{ }^{2} \lambda_{3}=[(1-2 \kappa) \lambda+2 \kappa] \\
& \lambda_{1}=\lambda_{2}, \quad \lambda_{3}=\lambda
\end{aligned}
$$

ここに火はポアソン比である。

したがって配向分布関数 $N(\Omega, \omega)$ は(21)式となる。

$$
N_{1}(\Omega, \omega)=\frac{N}{4 \pi} \cdot \frac{\beta_{2}^{\prime}}{\left[\beta^{\prime 2} \lambda^{-2} \cos ^{2} Q_{\lambda}+\beta^{\prime} \lambda_{\sin ^{2}} \Omega_{\lambda}\right]^{3 / 2}}
$$

$Z$ 軸（延伸軸）に対する方向余弦二乗平均は（22）式と なる。

$$
\left\langle\cos ^{2} \Omega\right\rangle=\frac{\lambda^{3} / \beta^{\prime}}{\left(\lambda^{3} / \beta^{\prime}\right)-1}\left\{1-\frac{\tan ^{-1}\left[\left(\lambda^{3} / \beta^{\prime}\right)-1\right]^{1 / 2}}{\left[\left(\lambda^{3} / \beta^{\prime}\right)-1\right]^{1 / 2}}\right\}
$$

(22) 式は同じ変形㳯であってもポアンン比が減少す るとともに〈 $\left.\cos ^{2} \Omega\right\rangle か ゙$ 減少することを示している。

ここで配向単位を結晶分子鎖軸にとると，(22)式に和 いて $\beta^{\prime}=1$ すなわら $\kappa=0.5$ によって予想される配向 挙動は膨潤 PVA, PSt, エチレンープロピレンランダム 共重合体和よび膨潤 PE などの比較的結晶性が低いか, 結晶ラメラ間の相互作用性が低いと思われる系の配向挙 動とよく合致し，これは Kratky による floating rod modelによる配向に相当する。佐藤によってもほぼ同様 のとりあつかいがなされている。したがってこれらの系 に执いて結晶ラメラをつなぐ連結鎖 (tie chain) によっ て変形が支配されるものと推定される。

\section{9-3. アフィン変形の修正}

isotactic-PP および PB-1 の無配向皮膜の延伸初期に 和いて複屈折が負值で亟小值を示す特異現象，あるいは $\mathrm{PE}$ を始めとする高結晶性の球晶を含を皮膜の延伸初 期の配向挙動の特異性を理解するためには，上述のよう な単純なモデルでは説明されず結晶高次組織の变形を反 
映させる必要がある。

一方力学的な立場から考察すると通常のアフィン変形 は homogeneous strain hypothesis 考觉られる。しかしながら結晶性高分子の力学的性質は むしろ homogeneous stress hypothesis に近いことを 示してお拈り,力学的な立場からもアフィン变形を修正す べきであろう。

アフィン変形の修正に際してはまず配向単位を何にと るかが問題となる。現在まで結晶分子鎖軸を配向軸とす る場合と結晶ラメラ軸（結晶ラメラ生長軸）を配向軸と する場合との二と扔りの方法がある。以下に PEをモデ ル物質として述べる。

\section{9-4. 結晶ラメラ軸を配向軸としたモデル}

現在をで三つのモデルが提案されている。

9-4-1. Sasaguri-Hoshino-Stein ${ }^{7)}$ おび SasaguriYamada-Stein ${ }^{82)}$ のモデル

Sasaguriらは上述の複屈折の特異現象を表現するため に, 球晶の変形に際して配向単位として結晶ラメラ軸を とり，結晶ラメラ軸の配向飞伴い結晶ラメラ軸（PE では結晶 $\mathrm{b}$ 軸, PP では結晶 $\mathrm{a}$ 軸, 以下は PE の結晶 軸によって述べる）から結晶分子鎖軸（結晶 $\mathrm{c}$ 軸）への 転換による phase transformation（折りたたみ結晶の 分子鎖とき住ぐし）を考慮して数式化を試みた。第21図 (b) および（c）にそのモデルを示す。

未変形時の結晶ラメラ軸に対する㵶維状結晶の分率を $X_{c, c, 0,}$ 变形後のその分率を $X_{c, c}$ とし, 結晶転換は球晶 変形に際して未変形時の半径より大きい半径に执いての 又起こると仮定すると（23）拈よび（24）式が得られる。

$$
\begin{array}{ll}
X_{c},{ }_{c}=X_{c, c, 0} & R<R_{0} \\
X_{c},{ }_{c}=X_{c, c, 0}+\gamma\left[\left(R / R_{0}\right)-1\right] & R \leq R_{0}
\end{array}
$$

ここでパラメーターケは折りたたみ結晶から繊維状結 晶への転換の容易さを示すコンプライアンスである。高 原らは（23）蛙よび（24）式をさらに連続関数型への修 正を試みているが58 ここでは省略して，(23）打よび (24）式を用いさらに Moore ${ }^{28)}$ とる $\beta^{\prime}$ を導入した結

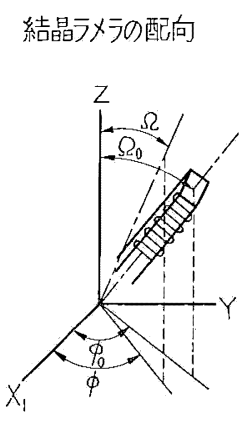

(a)

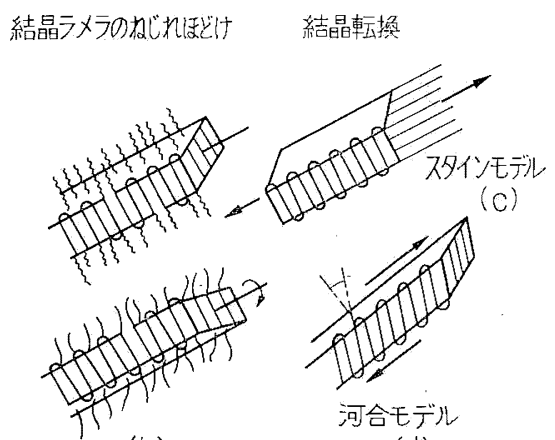

(b) (d)
第 21 図各球晶変形に用いられた各ユニットの変形 モデル
晶各軸の配向敊よび複屈折挙動の数式化を示す。

i）結晶 $\mathrm{b}$ 軸の配向 結晶 $\mathrm{b}$ 軸と延伸軸 $Z$ とのなす 角を $\beta$ とし，結晶ラメラ中の繊維状結晶中の結晶 $\mathrm{b}$ 軸が ラメラ軸と延伸軸とを含む平面となす角を $k, k$ の分布 を $M(k)$ とすると $\cos \beta$ は (25) 式および〈 $\left.\cos ^{2} \beta\right\rangle$ は

(26) 式で与兄られる。

$$
\cos \beta=\cos k \cdot \sin \Omega
$$

$$
\begin{aligned}
\left\langle\cos ^{2} \beta\right\rangle & =\int_{0}^{\pi} N(\beta) \cos ^{2} \beta d \beta \\
& =\int_{\Omega=0}^{\pi} \int_{k=0}^{2 \pi} N^{\prime}(\Omega \lambda, k) \sin ^{2} \Omega^{2} \cos ^{2} k d k d \Omega_{\lambda} \\
& =\int_{0}^{\pi} N_{2}\left(\Omega_{\lambda}\right) \sin ^{3} \Omega_{\lambda}\left\{\int_{0}^{2 \pi} M_{\Omega}(k) \cos ^{2} k d k\right\} d \Omega_{\lambda} \\
& =\int_{0}^{\pi} N_{2}\left(\Omega_{\lambda}\right) \sin ^{3} \Omega_{\lambda}\left\langle\cos ^{2} k\right\rangle_{\Omega} d \Omega_{\lambda}
\end{aligned}
$$

ここで $M(k)$ を入斿よ゙ $\Omega$ の何らかの関数に仮定す ることが合理的であろう。ここでは結晶転換後の㵶維状 結晶構造の仮定から $M(k)$ としてランダム分布を仮定す ると（27）式を得る。

$$
\left\langle\cos ^{2} k\right\rangle_{\Omega}=\frac{1}{2}
$$

したがって〈 $\left.\cos ^{2} \beta\right\rangle$ は (28) 式となる。

$$
\left\langle\cos ^{2} \beta\right\rangle=\int_{0}^{\pi} N_{2}\left(\Omega_{\lambda}\right) \sin ^{3} \Omega_{\lambda}\left(\frac{1}{2}\right) d \Omega_{\lambda}
$$

一方ラメラ中の折りたたみ結晶中では, ラメラのねじ れにかかわらず結晶 $\mathrm{b}$ 軸は常にラメラ軸に一致するの で〈 $\left.\cos ^{2} \beta\right\rangle$ は (18) 式で与光られる。

$$
\left\langle\cos ^{2} \beta\right\rangle=\int_{0}^{\pi} N_{1}\left(\Omega_{\lambda}\right) \sin \Omega_{\lambda} \cos ^{2} \Omega_{\lambda} d \Omega_{\lambda}
$$

したがって（28）和よび（29）式によって表わされる 〈 $\left.\cos ^{2} \beta\right\rangle$ にそれぞれ分率を考慮すると（30）式を得る。

$$
\begin{aligned}
\left\langle\cos ^{2} \beta\right\rangle= & \frac{1}{N}\left[\int_{0}^{\pi}\left(1-X_{c c}\right) N\left(\Omega_{\lambda}\right) \sin \Omega_{\lambda} \cos ^{2} \Omega_{\lambda} d \Omega_{\lambda}\right. \\
& \left.+\int_{0}^{\pi} X_{c c} N\left(\Omega_{\lambda}\right) \sin ^{3} \Omega_{\lambda}\left(\frac{1}{2}\right) d \Omega_{\lambda}\right]
\end{aligned}
$$

ここで先の Moore の $\beta^{\prime}$ を導入して一般的な記述を行 ならと， $R / R_{0}$ は (31) 式で示される。

$$
R / R_{0}=\left(\lambda^{-2} \cos ^{2} \Omega_{\lambda}+\lambda \beta^{\prime-1} \sin \Omega_{\lambda}\right)^{-1 / 2}
$$

したがって結晶b軸の配向係数 $F_{\beta}$ は (32) 式 となる。

$$
\begin{aligned}
F_{\beta} & =\frac{3\left\langle\cos ^{2} \beta\right\rangle-1}{2} \\
& =\frac{3\left\langle\cos ^{2} \Omega_{\lambda}\right\rangle-1}{2}\left(1+\frac{3 \gamma}{2}\right)+\frac{3}{2} \cdot \frac{\gamma \lambda}{2} \\
& \times\left[1-\frac{3 a+1}{2}\left(1-\frac{a^{1 / 2} \tanh ^{-1} a^{-1 / 2}}{\lambda^{3} / \beta^{\prime}}\right)\right] \\
& +\frac{3}{2} X_{c, c, 0} \frac{3\left\langle\cos ^{2} \Omega_{\lambda}\right\rangle-1}{2} \\
& a=\left(\lambda^{3} / \beta^{\prime}\right)\left[\left(\lambda^{3} / \beta^{\prime}\right)-1\right]
\end{aligned}
$$


さらに結晶 $\mathrm{a}$ 軸の配向係数 $F_{\alpha}$ は (34) 式となる。

$$
F_{\alpha}=\frac{3\left\langle\cos ^{2} \alpha\right\rangle-1}{2}=\frac{1-3\left\langle\cos ^{2} \Omega_{\lambda}\right\rangle}{4}
$$

ii）結晶 $\mathbf{c}$ 軸の配向 Kawai らは低密度 PE の結 晶各軸の配向係数の実測值と（30）および（31）式に括 いて $\beta=1$ とした計算值との比較を行なった結果, 結晶 $\mathrm{a}$ 韩が計算值よりさらに進むこと拈よび $X_{c, 0,0}$ を相当 大きな值にしないかぎり実測值を説明しえないことを示 した ${ }^{45)}$ 。

Sasaguri ら ${ }^{822}$ はこれらの不備を補らためさらに結晶 $\mathrm{b}$ 軸まわりの結晶 $\mathrm{a}$ および $\mathrm{c}$ 軸の回転機構をパラメータ ー られる。

$$
g=2\left\langle\cos ^{2} \kappa\right\rangle-1=\eta(\lambda-1) \sin ^{2} \Omega_{\lambda}
$$

ここでんは結晶 $\mathrm{c}$ 軸と延伸軸特よびラメラ軸とでつく る平面とのなす角である。さらにりは回転のしやすさの パラメーターである。この結果結晶 $\mathrm{c}$ 軸の 配向係数 $F_{\varepsilon}$ は（36）式となる。

$$
\begin{aligned}
F_{\varepsilon}= & \frac{3\left\langle\cos ^{2} \varepsilon\right\rangle-1}{2}=\frac{1}{2} \cdot \frac{3\left\langle\cos ^{2} \Omega_{\lambda}\right\rangle-1}{2} \\
& \times\left[1+\eta \frac{\lambda-1}{2}\{2 \gamma-a(1+3 \gamma)\}\right]-\frac{3\left\langle\cos ^{2} \beta\right\rangle-1}{2} \\
& \times[1-\eta(\lambda-1)(a-1)]+\frac{\eta(\lambda-1)}{2} \cdot \frac{\gamma+1}{2} \\
& +X_{c}, c,\left[\frac{3\left\langle\cos ^{2} \Omega_{\lambda}\right\rangle-1}{2}\left(\frac{3}{2}+\frac{\eta(\lambda-1)(1-3 a)}{4}\right)\right. \\
& \left.-\frac{1}{2} \cdot \frac{\eta(\lambda-1)}{2}\right]
\end{aligned}
$$

この場合結晶 $\mathrm{a}$ 朝の配向係数は（32）拈よび（36）式 から計算で得る。

iii）実験結果との比較（32），(36）㧊よび (12) 式により結晶 $\mathrm{a}, \mathrm{b}$ 打よび $\mathrm{c}$ 軸の配向の球晶の変形倍率 スに対する変化を算出することができる。第 22 図 (a)

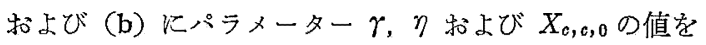
適当に仮定し計算した結晶 b拉よび $\mathrm{c}$ 軸の配向举動と著 者らの実験結果との比較を示す ${ }^{-28)}$ 。ここで球晶の変形 率は皮膜の延伸率と同じとしている。

結晶口軸の配向挙動の理論と実験結果を比較すると, パラメーター $X_{0, c, 0}$ 叔よび $\gamma$ の值をかなり大きくとら ないかぎり結晶 $\mathrm{b}$ 軸の負配向は得られないことがわか る。たと党ば $X_{o, c, 0}=0, \gamma=0$ では球晶の未変形時に結 晶ラメラはすべて折りたたみ結晶からなり, 球晶の変形 ととるに結晶ラメラ軸が結晶転換することなく延伸軸に 配向することを意味し, 結晶ラメラ軸 ( $b$ 軸) の強い正 配向を与兄る。一方結晶 $\mathrm{c}$ 朝の配向挙動索比较すると变

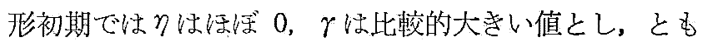
に変形倍率とともに増大すると考光ると実験結果をよく 説明する。

換言すれば Sasaguri ら ${ }^{67), 82)}$ のモデル的表現は

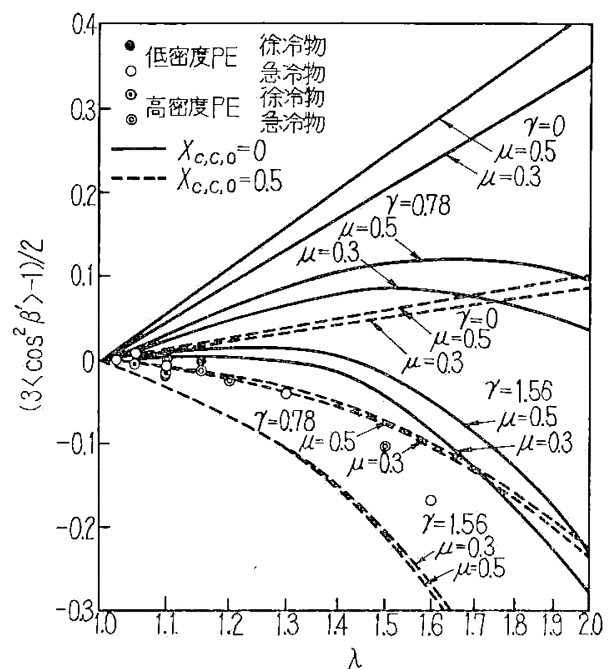

(a)

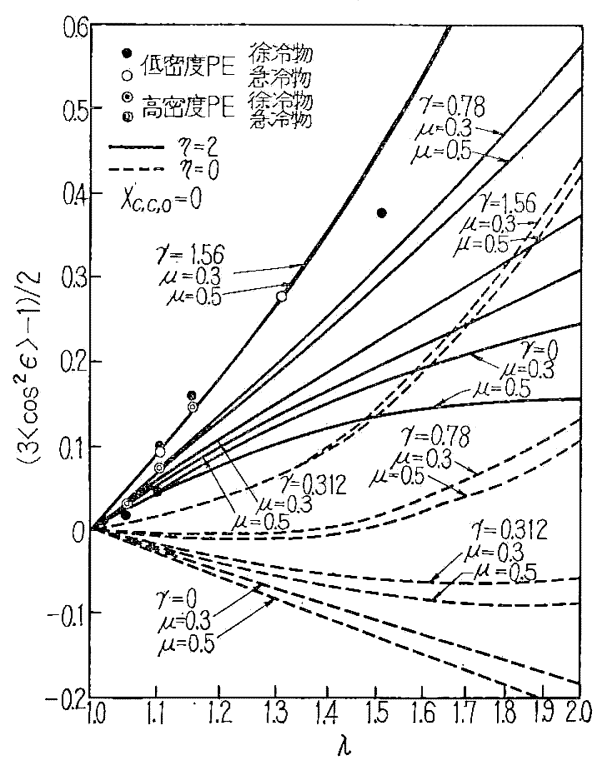

(b)

第 22 図 Moore によるStein らのモデルによる 結晶配向挙動, J. Polymer Sci., 5, A-2, 711 (1967)

（a）球晶中の結晶ラメラは未变形時飞おいても約 $50 \%$ 程度の縐維状結晶を含み

（b）主として球晶側面での結晶ラメラの回転を伴う 変形は球晶変形初期にはほとんぞ起こらないが

（c）主として球晶内の延伸軸汇近い結晶ラメラ軸の 延伸に伴らミクロネッキングによる分子鎖とき侣ぐしは 球晶変形初期飞执いて子容易に起こり入の增大に対して

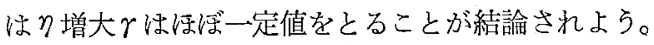

\section{9-4-2. 複屈折}

Sasaguri らが複屈折に対して同じモデルにより計算 し67) Moore が一般化28) した式を(37) 式に示す。 
(a)

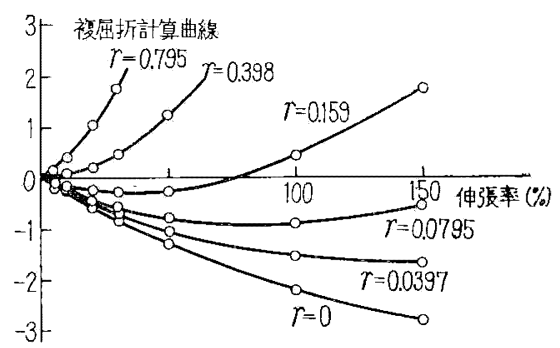

(b)

第 23 図 (a) 延伸温度の差異による複屈折变化の 差異, (b) Stein らのモデルによる複属 折の計算值, J. Appl. Phys., 35, 47 (1964)

$$
\begin{aligned}
\Delta= & \Delta_{u}\left[\frac{3\left\langle\cos ^{2} \Omega_{\lambda}\right\rangle-1}{2}\right]+\frac{2}{3}\left[\Delta_{s}-\Delta_{u}\right] \\
& \times\left[\frac{3\left\langle\cos ^{2} \Omega_{\lambda}\right\rangle-1}{2}-\frac{3\left\langle\cos ^{2} \beta\right\rangle-1}{2}\right]
\end{aligned}
$$

ここで $\Delta_{u}$ および $\Delta_{s}$ は (38) 和よび (39) 式で与え られ，それぞれ球晶の半径方向に結晶 $\mathrm{b}$ 軸および結晶 $\mathrm{c}$ 軸を有する場合の複屈折を示す。

$$
\Delta_{u}=n_{b}-\frac{n_{a}+n_{c}}{2}
$$

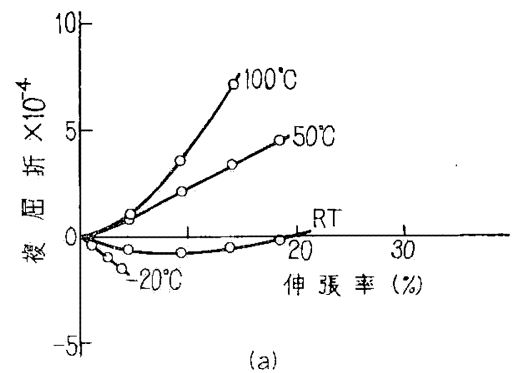

$$
\Delta_{s}=n_{c}-\frac{n_{a}+n_{b}}{2}
$$

第 23 図（b）は（37）式に（19）拈よび(34) 式を代 入し， $\beta^{\prime}=1$ として $\gamma$ を变化させた計算值の変化と PP 皮膜について延伸温度を变化させた場合の複屈折变化之 の比較を示寸。これからわかるよらに延伸温度が上昇に 伴ら複屈折变化は， $\gamma$ すなわら変形のしやすさのパラ人 一ターを大きくとれば定性的に説明される。PP および PB-1 皮膜の経時効果による複屈折变化も同様に説明で きる。

\section{9-4-3. Oda-Nomura-Kawai のモデル ${ }^{49)}$}

上述 Sasaguri $5^{67)}$ のデルと同様配向単位を結晶ラ メラ軸にとり，結晶ラメラの配向に伴い結晶a軸をわり 拉よび b 軸恋わりの回転を考慮したもので観念的には Sasaguri らのモデルK拮る急激な結晶転換を徽結晶 の、軸まわりの回転に和きかえたモデルといえよう。 したがって詳しい定式化の説明は省略し Mooreにより 一般化された結果のみを示す。そのモデルを第 21 図 (b) 扎よび (d) に示す。

たとえば結晶 $\mathrm{a}$ 軸の延伸軕に対する 余获二乗平均は (40) 式で示される。

$$
\begin{aligned}
\left\langle\cos ^{2} \alpha\right\rangle= & (2 / N)\left[\int_{\Omega=0}^{\Omega_{0}} N\left(\Omega_{\lambda}\right) \sin ^{3} \Omega_{\lambda}(1 / 2) f_{\Omega}{ }^{n} d \Omega_{\lambda}\right. \\
& +\int_{\Omega_{0}}^{\pi / 2} N\left(\Omega_{\lambda}\right) \sin ^{3} \Omega_{\lambda}(1 / 2) f_{\Omega}^{-n} d \Omega_{\lambda}
\end{aligned}
$$

ここで $Q_{0}$ は $R=R_{0}$ となる角で (41) 式で与えられ る。

\begin{tabular}{|c|c|}
\hline$n$ & $\left(3\left\langle\cos ^{2} \alpha\right\rangle-1\right) / 2$ \\
\hline$\frac{1}{3}$ & $\begin{array}{c}\frac{3}{4}\left(\frac{\beta}{\lambda^{3}}\right)\left[a+(1-a)^{1 / 2} \tanh ^{-1}\left(\frac{1}{a}\right)^{1 / 2}\right]+\frac{3}{4}\left(\frac{\beta}{\lambda^{3}}\right)^{1 / 3}\left[a-1+\frac{1}{2}\left(\frac{\beta}{\lambda^{3}}\right)^{1 / 3}(1+a) a^{1 / 2} \tanh ^{-1}\left(\frac{\cos \theta_{0}}{a^{1 / 2}}\right)\right. \\
\quad+\frac{3}{4}\left(\frac{\beta}{\lambda^{3}}\right)^{1 / 3} a\left[\frac{1-a}{2}\left(\frac{\beta}{\lambda^{3}}\right)^{1 / 3} \frac{\cos \theta_{0}}{\left(a-\cos ^{2} \theta_{0}\right)}-\cos \theta_{0}\right]-\frac{1}{2}\end{array}$ \\
\hline 1 & $\begin{array}{l}\frac{3}{16}\left(\frac{a^{2} \beta}{\lambda^{3}}\right)\left\{\frac{(1-a) \cos \theta_{0}}{\left(a-\cos ^{2} \theta_{0}\right)^{2}}+\left(\frac{3+a}{2 a}\right)\left[\frac{\cos \theta_{0}}{a-\cos ^{2} \theta_{0}}+a^{-1 / 2} \tanh ^{-1}\left(\frac{\cos \theta_{0}}{a^{1 / 2}}\right)\right]\right\} \\
\quad+\frac{1}{4} \cos \theta_{0}\left(\cos ^{2} \theta_{0}-3\right)\end{array}$ \\
\hline$m+n$ & $\left(3\left\langle\cos ^{2} \beta\right\rangle-1\right) / 2$ \\
\hline$\frac{1}{3}$ & $\begin{array}{l}\frac{3 a}{2}\left(\frac{\beta}{\lambda^{3}}\right)^{1 / 3}\left[\cos \theta_{0}-1+a^{1 / 2} \tanh ^{-1}\left(a^{-1 / 2}\right)-a^{1 / 2} \tanh ^{-1}\left(a^{-1 / 2} \cos \theta_{0}\right)\right] \\
\quad+\frac{3 a^{3 / 2}}{2}\left(\frac{\beta}{\lambda^{3}}\right)^{1 / 2}\left\{\frac{\cos \theta_{0}}{\left(a-\cos ^{2} \theta_{0}\right)^{1 / 2}}-\tan ^{-1}\left[\frac{\cos \theta_{0}}{\left(a-\cos ^{2} \theta_{0}\right)^{1 / 2}}\right]\right\}-\frac{1}{2}\end{array}$ \\
\hline 1 & $\frac{3}{2}\left(\frac{\beta}{\lambda^{3}}\right)^{1 / 2}\left(\frac{\lambda^{3} / \beta}{\left(\lambda^{3} / \beta\right)-1}\right)^{3 / 2}\left\{\frac{\cos \theta_{0}}{\left(a-\cos ^{2} \theta_{0}\right)^{1 / 2}}-\tan ^{-1}\left[\frac{\cos \theta_{0}}{\left(a-\cos ^{2} \theta_{0}\right)^{1 / 2}}\right]\right\}-\frac{1}{2} \cos ^{3} \theta_{0}$ \\
\hline
\end{tabular}

$$
\Omega_{0}=\cos ^{-1}\left[\frac{\left(\lambda^{3} \beta^{\prime-1}-\lambda^{2}\right)}{\left(\lambda^{3} \beta^{\prime-1}-1\right)}\right]^{1 / 2}
$$

$n$ は結晶b軸まわりの回転のしやすさであり， $f_{\Omega}$ は回 転の程度を表わすパラメーターで円推体の立体角变化の

第 3 表 


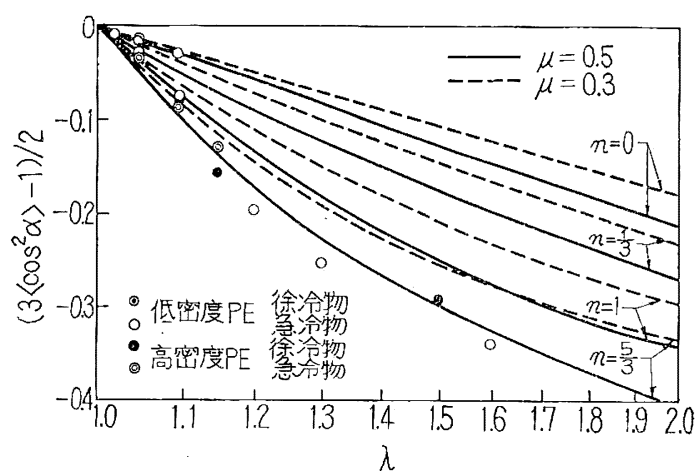

(a)

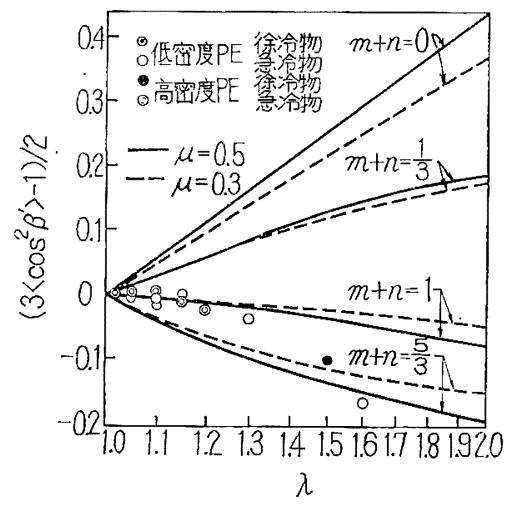

(b)

第 24 図 Moore による Oda らのモデルによる 結晶配向挙動, J. Polymer Sci., 5, A-2, 711 (1967)

関数として次式のように与える。

$$
f_{\Omega}(\lambda, \omega)=\left(R_{0} / R\right)^{3} \lambda_{1} \lambda_{2} \lambda_{3}=\left(R_{0} / R\right)^{3} \beta^{\prime}
$$

一方結晶 $\mathrm{b}$ 軸の延伸軸に対する方向余弦の二乘平均は

(43) 式で示される。

$$
\begin{array}{r}
\left\langle\cos ^{2} \beta\right\rangle=(2 / N)\left[\int_{\Omega=0}^{\Omega_{0}} N\left(\Omega_{\lambda}\right) \sin \Omega_{\lambda} \cos ^{2} \Omega_{\lambda} f_{\Omega}{ }^{(m+n)} d \Omega_{\lambda}\right. \\
\left.+\int_{\Omega_{0}}^{\pi / 2} N\left(\Omega_{\lambda}\right) \sin \Omega_{\lambda} \cos ^{2} \Omega_{\lambda} d \Omega_{\lambda}\right]
\end{array}
$$

ここで㵀晶軸おわりの結晶 $\mathrm{b}$ 京よび $\mathrm{c}$ 軸の回転の しやすさを示すパラメーターである。

第 3 表に $F_{\alpha}=\left(3\left\langle\cos ^{2} \alpha\right\rangle-1\right) / 2$ 和よび $F_{\beta}=\left(3\left\langle\cos ^{2} \beta\right\rangle\right.$ -1)/2 種々の $n$ 拈よび $m$ について示す。

第 24 図は第 3 表各式の計算結果と実験結果との比較 を示す。比較の結果, 球晶の変形倍率の増大とともに の值を $0 \rightarrow 2, m+n$ の值を $1 \rightarrow 2$ すなわち $m$ を $1 \rightarrow 0$ に 变化させればほぼ奏験結果を記述しらることがわかる。

以上結論的に次のことが示される。

（a）球晶は未変形時に执いては結晶ラメラはすべて 結晶 $\mathrm{b}$ 軸がラメラ軸となっている。

(b) 球晶の変形初期に执いては結晶ラメラの結晶 $\mathrm{a}$

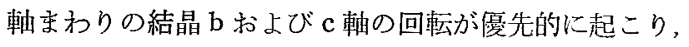

結晶ラメラ軸 ( $b$ 軸) 妄わりの結晶 $\mathrm{c}$ 軸㐨よび $\mathrm{a}$ 軸の回 転はほとんど起こらない。

(c) 変形の增大とともに結晶ラメラの权じれが顕著 になり，結晶a軸まわりの回転は減退する。

\section{9-4-4. 多重殻モデル}

2-3.ですでに述べたよらに球晶の変形はみかけ上均 一変形であっても中心部汪ど変形倍率が大きいという観 察結果がある。これに対してWilchinskyによって提案 された多重殼モデルと著者らのモデルを組合せたモデ ル56)を考えることができる。その訃算結果から球款数を 增加することにより各結晶軸の配向挙動を強調すること がでさる。この場合は一般に球殼数が配向単位の大きさ と関連するものと考えられよう。

\section{9-5. 結晶分子鎖軸を配向軸としたモデル ${ }^{88)}$}

\section{9-5-1. 伸張変形に伴う配向挙動}

上述したよらに結晶性の高い場合と低い場合で異なっ たモデルにより説明されることを示した。しかしながら たとえば 4-6、で示したように種々の環境条件で結晶各 軸の配向挙動が異なることを説明するためには同じモデ ルにより説明できることが望ましい。ここで結晶 $\mathrm{c}$ 軸を 配向軸としたモデルを考えてみる。

いま第 25 図に示すように結晶面が互いに向い合った 二つの微結晶（二つの微結晶は互いに速結鎖でつながれ ている）の中心を結ぶベクトルを考える。このベクトル は一軸伸張に際してアフィン変形則に従らと考えられ る。ここで結晶性が低く一つの微結晶が他の微結晶ある いは連結鎖により特別な制約を受けないと考えられる場 合には結晶分子鎖軸とベクトルの方向が一致しアフィン 変形則に従い，この場合を一つの基準状態と考えること にする。これは Kratky の floating rod mode1 ${ }^{55)}$ ある いは Wilchinsky の理想一軸変形 ${ }^{83)}$ と一致する。PEの 結晶各軸に対して第 21 図のように角度を定義すると方 向余弦二乗㹥それぞれ次式となる。

$$
\begin{aligned}
& \cos ^{2} \alpha=\sin ^{2} \Omega_{\lambda}\left\langle\overline{\cos ^{2} \xi^{\prime}}\right\rangle=\frac{1}{2} \sin ^{2} \Omega_{\lambda} \\
& \cos ^{2} \beta=\sin ^{2} \Omega_{\lambda}\left\langle\overline{\sin ^{2} \xi^{\prime}}\right\rangle=\frac{1}{2} \sin ^{2} \Omega_{\lambda} \\
& \cos ^{2} \varepsilon=\cos ^{2} \Omega_{\lambda}
\end{aligned}
$$

しかしながら絬晶性が高くなると結晶ラメラおよび結 晶ラメラ間連結鎖の性状変化による効果により二つの貒 結晶間の相互作用性が増大し結晶各軸が特殊な配向挙動 を示すようになると考兄られる。すなわち結晶ラメラの 異方性が顕著になるとともに系沈和方密度の増加をる たらす。したがって相連なる二つの結晶ラメラ間の間隔 が減少するとともに接触面積が增大し結晶ラメラ間に方 向性をもった相互すべりが起こりやすくなると考えられ る。さらに結晶ラメラ間の有効連結鎖の分布密度の增加 


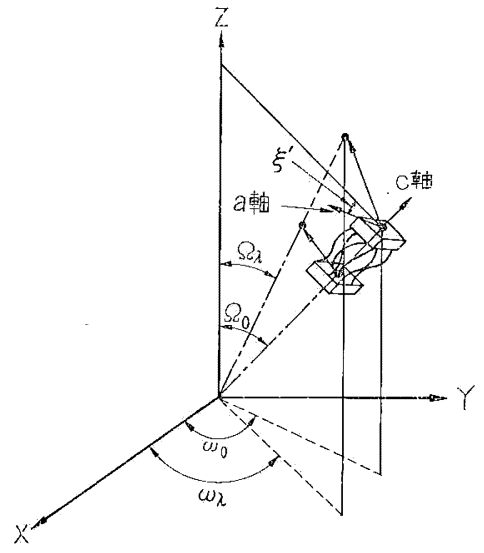

第 25 図 配向単位のモデルおよび角 $\Omega_{0}, \Omega_{\lambda}$, $\omega_{0}, \omega_{\lambda}$ 拉よび $\xi^{\prime}$ の定義

およびその長さの減少とともに，伸張に伴ら連結鎖の緊 張は低結晶性の場合と比べて著しくなるであるう。した がってここでさらに結晶の $\mathrm{a}$ 軸抒よび b軸要わりの回転 を考虑することにより修正する必要がある。

定式化漈しては非晶鎖の緊張依存すると考吕られ る回転の項と結晶ラメラ間のすべりとよる回転の項に分 けて考克る。

非晶鎖の緊張による回転は第 26 図に示されるように 試料に固定した O-X, Y, Z 座標系 (Carlesian) と微結晶 内に固定した O-x, y, z座標系 (Carlesian) をEuler 角 $\left(\Omega_{\lambda}, \xi^{\prime}, \omega_{\lambda}\right)$ により関係ずけ,さら結晶 $\mathrm{a}$ 軸 $(\mathrm{x}$ 軸) 㧊よびb軸 ( $\mathrm{y}$ 軸) 变わりの回転操作により定式化され る。

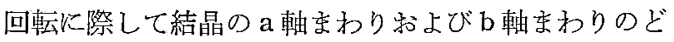
ららを優先させるかにより異なる結果を得る。奏際の回 転が両者の中間であることを考光, 両者についてそれぞ れ計算を行ない，結晶 $\mathrm{a}$ 抒よび $\mathrm{b}$ 軸の延伸軸 $Z$ に対する 方向余弦二乗に対する結晶 $\mathrm{a}$ 軸ふわりの回転が優先する パラメーター（分率）をいで表わすと次式となる。

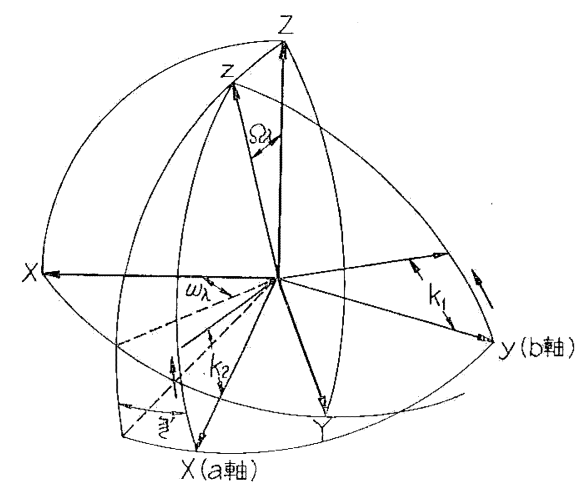

第 26 図角 $\Omega_{\lambda}, \omega_{\lambda}, \xi^{\prime}$ および結晶 a 軸执よびb 軸まわりの回転角 $k_{1}$ 打よび $k_{2}$ の定義 $\cos ^{2} \alpha^{\prime}=\frac{1}{2} \sin ^{2} \Omega_{\lambda} \cos ^{2} k_{2}+\cos ^{2} \Omega_{\lambda} \sin ^{2} k_{2}$

$$
-w \sin ^{2} k_{2} \sin ^{2} k_{1}\left(1-\frac{3}{2} \sin ^{2} \Omega\right)
$$

$\cos ^{2} \beta^{\prime}=\frac{1}{2} \sin ^{2} \Omega_{\lambda} \cos ^{2} k_{1}+\cos ^{2} \Omega_{\lambda} \sin ^{2} k_{1}$

$$
\begin{aligned}
& +(1-w)\left\{\frac{1}{2} \sin ^{2} \Omega_{\lambda} \sin ^{2} k_{1} \sin ^{2} k_{2}\right. \\
& \left.-\cos ^{2} \Omega_{\lambda} \sin ^{2} k_{1} \cos ^{2} k_{2}\right\}
\end{aligned}
$$

ここで結晶 $\mathrm{a}$ 軸扣よび $\mathrm{b}$ 軸まわりの回転角 $k_{1}$ 特よび $k_{2}$ は砒伸軸 $Z$ と $z$ 軸とのなす角 $\Omega_{\lambda}$ 亿依存すると考克 られ， $\Omega_{\lambda}$ が $90^{\circ}$ に近い汪ど大きくなるであるう。さらに $k_{1}$ および $k_{2}$ は球晶の変形率 $\lambda$ に依存寸ると考光られ る。したがって $k_{1}$ 预よび $k_{2}$ を次式で近似する。

$$
\begin{aligned}
& \sin ^{2} k_{1}=\eta_{1}(\lambda-1) \sin ^{2} \Omega_{\lambda} \\
& \sin ^{2} k_{2}=\eta_{2}(\lambda-1) \sin ^{2} \Omega_{\lambda}
\end{aligned}
$$

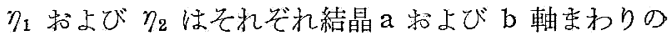
微結晶の回転のコンプライアンスである。

一方結晶ラメラ面にそったすべり变形による回転はラ メラ面にそったせん断応力の関数と考えられる。せん断 灾力 $\tau$ は延伸軸にそった伸張㐫力 $\sigma$ に対して一般に次式 となる ${ }^{92)}$ 。

$$
\tau=\sigma \sin \Omega_{\lambda} \cos \Omega_{\lambda}
$$

したがってせん断応力によりもたらされる配向变化は 結晶 $\mathrm{a}$ 扰よ゙ $\mathrm{b}$ 軸の力向余弦二乗に比較して次式と仮定 できよう。

$$
\begin{aligned}
& \Delta\left(\cos ^{2} \alpha\right)=\eta_{1}{ }^{\prime}(\lambda-1) \cos ^{2} \Omega_{\lambda} \sin ^{2} \Omega_{\lambda} \\
& \Delta\left(\cos ^{2} \beta\right)=\eta_{2}{ }^{\prime}(\lambda-1) \cos ^{2} \Omega_{\lambda} \sin ^{2} \Omega_{\lambda}
\end{aligned}
$$

$\eta_{1}^{\prime}$ 执よび $\eta_{2}^{\prime}$ はそれぞれ結晶a打よび b 軸方向のす ベりのコンプライアンスである。

ここで（47）牛よび（48）式にそれぞれ（52）および （53）式を加え，(49）执よび（50）式を代入した後，高 次の項を省略すると次式を得る。

$$
\begin{aligned}
\cos ^{2} \alpha \cong & \frac{1}{2} \sin ^{2} \Omega_{\lambda}\left\{1-\eta_{2}(\lambda-1) \sin ^{2} \Omega_{\lambda}\right. \\
& \left.+2\left(\eta_{2}+\eta_{1}{ }^{\prime}\right)(\lambda-1) \cos ^{2} \Omega_{\lambda}\right\} \\
\cos ^{2} \beta \cong & \frac{1}{2} \sin ^{2} \Omega_{\lambda}\left\{1-\eta_{1}(\lambda-1) \sin ^{2} \Omega_{\lambda}\right. \\
& \left.+2\left(\eta_{1}+\eta_{2}{ }^{\prime}\right)(\lambda-1) \cos ^{2} \Omega_{\lambda}\right\}
\end{aligned}
$$

（54）拉よび (55) 式を（44）扝よび（45）式と比較す ることにより\{\} 内は基準状態からの背位を表わす関 数と考皇ることができる。ここで背位を表わす関数をそ れぞれ $G_{\alpha}$ および $G_{\beta}$ とすると次式となる。

$$
\begin{aligned}
& \cos ^{2} \alpha=\frac{1}{2} \sin ^{2} \Omega_{\lambda} G_{\alpha} \\
& \cos ^{2} \beta=\frac{1}{2} \sin ^{2} \Omega_{\lambda} G_{\beta}
\end{aligned}
$$

$G_{\alpha}$ 拉よび $G_{\beta}$ を未変形時の角 $\Omega_{0}$ をもらいて次式で 
近似する。

$G_{\alpha} \cong\left\{1-\eta_{2}(\lambda-1) \sin ^{2} \Omega_{0}+2\left(\eta_{2}+\eta_{1}{ }^{\prime}\right)(\lambda-1) \cos ^{2} \Omega_{0}\right\}$

$G_{\beta} \cong\left\{1-\eta_{1}(\lambda-1) \sin ^{2} \Omega_{0}+2\left(\eta_{1}+\eta_{2}{ }^{\prime}\right)(\lambda-1) \cos ^{2} \Omega_{0}\right\}$

上式の近似により結晶の $\mathrm{a}$ 軸およよ゙ $\mathrm{b}$ 軸まわりの回転 の程度拉よび回転のコンプライアンスの球晶の各変形率 および非回復ひがみ率に対して明確な比較が可能とな る。

以上により結晶 $\mathrm{a}$ 和よび $\mathrm{b}$ 軸の各配向係数は次式にお いて $\eta_{1}, \eta_{2}, \eta_{1}{ }^{\prime}$ および $\eta_{2}{ }^{\prime}$ に適当な数値を代入するこ とにより計算が可能である。

$$
\begin{aligned}
F_{\alpha}=\frac{1}{N / 2}\left[\int_{0}^{2 \pi} \int_{0}^{\pi / 2} N\left(\Omega_{\lambda}, \omega_{\lambda}\right)\right. & P_{2}\left(\cos ^{2} \alpha\right) \\
& \left.\times \sin \Omega_{\lambda} d \Omega_{\lambda} d \omega_{\lambda}\right]
\end{aligned}
$$

$$
\begin{aligned}
F_{\beta}=\frac{1}{N / 2}\left[\int_{0}^{2 \pi} \int_{0}^{\pi / 2} N\left(\Omega_{\lambda}, \omega_{\lambda}\right)\right. & P_{2}\left(\cos ^{2} \beta\right) \\
& \left.\times \sin \Omega_{\lambda} d \Omega_{\lambda} d \omega_{\lambda}\right]
\end{aligned}
$$

$N$ は微結晶中心間ベクトルの総数であり， $N\left(\Omega_{\lambda}, \omega_{\lambda}\right)$ 注角 $\Omega_{\lambda}$ および $\omega_{\lambda}$ の分布関数である。

9-5-2. 変形した球晶の弾性回復に伴う配向回復挙動 変形した球晶が弾性回復する際に相連なる二つの微結 晶中心間ベクトルはアフィン变形に従って弾性回復する と考えられる。さらに結晶 $\mathrm{a}$ 軸および b軸まわりの回転 も同時に部分的に弾性回復すると考它られる。したがっ て球晶が弾性回復する前の変形率を $\lambda_{m}$ とすると (58)叔 よび（59）式は次式となる

$$
\begin{aligned}
G_{\alpha, m}= & {\left[1-\left(\lambda_{m}-1\right)\left\{\eta_{2} \sin ^{2} \Omega_{0}\right.\right.} \\
& \left.\left.-2\left(\eta_{2}+\eta_{1}{ }^{\prime}\right) \cos ^{2} \Omega_{0}\right\}\right] \\
G_{\beta, m}= & {\left[1-\left(\lambda_{m}-1\right)\left\{\eta_{1} \sin ^{2} \Omega_{0}\right.\right.} \\
& \left.\left.-2\left(\eta_{1}+\eta_{2}{ }^{\prime}\right) \cos ^{2} \Omega_{0}\right\}\right]
\end{aligned}
$$

変形した球晶の弾性回復に伴ら結晶 $\mathrm{a}$ 和よびb軸まわ

\begin{tabular}{|c|c|c|c|c|c|c|c|c|}
\hline \multicolumn{3}{|c|}{ Y-O-S＼cjkstart膨潤状態 } & $Y-C-5$ & \multicolumn{2}{|c|}{ 電子線嬖射 (少) } & \multicolumn{3}{|c|}{$\mathrm{M}-\mathrm{O}-\mathrm{S}$ 潤膨 } \\
\hline$Y-20$ & 延伸温度 & $20^{\circ} \mathrm{C}$ & $\mathrm{Y}-\mathrm{C}-80$ & " & (多) & $M-20$ & 濶延仲 & $20^{\circ} \mathrm{C}$ \\
\hline$Y-62$ & " & $62^{\circ} \mathrm{C}$ & $Y-C-5-S$ & " & 膨潤 & M-72 & " & $72^{\circ} \mathrm{C}$ \\
\hline$Y-84$ & " & $84^{\circ} \mathrm{C}$ & $Y-C-80-S$ & " & " & M-92 & " & $92^{\circ} \mathrm{C}$ \\
\hline
\end{tabular}

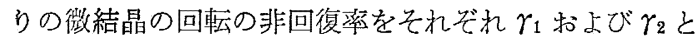
しせん断応力による変形悱回復性であると仮定すると 弾性回復後 $G_{\alpha}$ および $G_{\beta}$ は次式となる。

$$
\begin{aligned}
& G_{\alpha, m}, r_{2}=\left[1-\left(\lambda_{m}-1\right)\left\{\gamma_{2} \eta_{2} \sin ^{2} \Omega_{0}\right.\right. \\
&\left.\left.-2\left(\eta_{2} \gamma_{2}+\eta_{1}{ }^{\prime}\right) \cos ^{2} \Omega_{0}\right\}\right] \\
& G_{\beta, m}, \gamma_{1}= {\left[1-\left(\lambda_{m}-1\right)\left\{\gamma_{1} \eta_{1} \sin ^{2} \Omega_{0}\right.\right.} \\
&\left.\left.-2\left(\eta_{1} \gamma_{1}+\eta_{2}{ }^{\prime}\right) \cos ^{2} \Omega_{0}\right\}\right]
\end{aligned}
$$

第 4 表

$\mathrm{Y}-$ 低密度 PE, M- 高滵度 $\mathrm{PE}$

Vol. 18 , No. 213

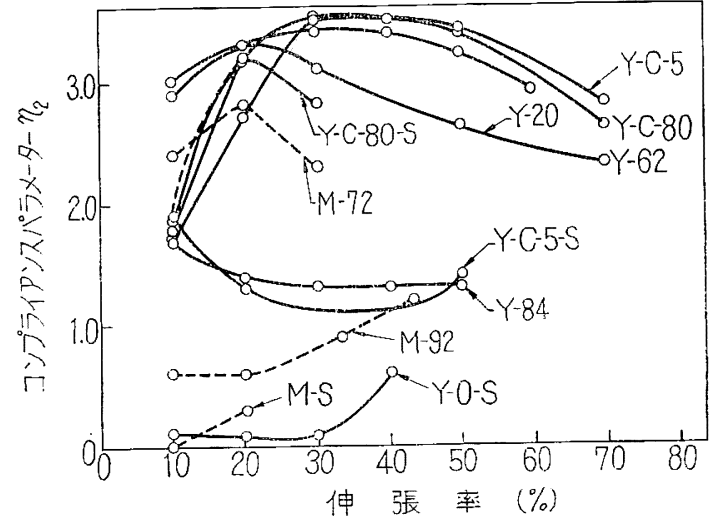

第 27 図結晶 $\mathrm{b}$ 軸まわりの回転のコンプライフン ス $\eta_{2}$ の伸張率依存性

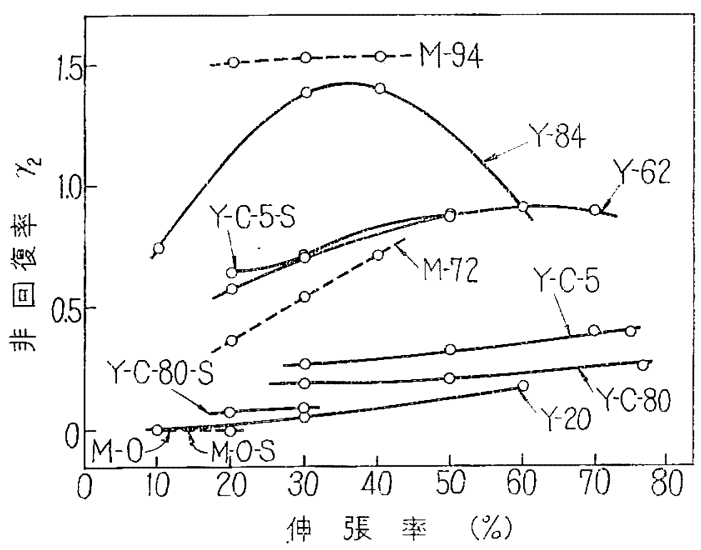

第 28 図結昆 $\mathrm{b}$ 軸まわりの回転の非弹性回複率 の伸張率依存性

\section{9-5-3. 実験との比較}

第 27 図掞よび第 28 図に低密度 $\mathrm{PE}(\mathrm{Y})$ 扎よび高密 度 $\mathrm{PE}(\mathrm{M})$ の種々の環境条件に打引る皮膜の一軸伸張お よび緊張弛緩に伴う結晶 $\mathrm{a}$ 軸の配向叔よび配向回復挙動 についての回折結果を示す。回折に際して $\eta_{1}{ }^{\prime}=0$ すな わち結晶ラメラ面間のすべりによる結晶 $\mathrm{a}$ 軸の配向に対 する笴与がないと仮定して，赛駼值に最もよくあうよう に $\eta_{2}$ を定めたるのである。試料の記号については第 4 表に示す。

第 27 図から明らかなことは各試料について釆統的な 結果が得られ，Y-20，Y-62，M-20 などの 江方皮膜の 伸張率 20〜60\%に拈いて極大を示し,かつ 2 以上の大き な值を示すグループと Y-O-S，Y-84 などの $\eta_{2}$ が極值 を示さずかつ值む小さいグループ に分かれる。先の極大を示すグル 一プは結晶ラメラの完全度が比較 的よいと考えられ，ラメラ単位の 変形が箸しいと考えられる。後者 は結晶ラメラの完全度がわるくラ メラ内微結晶単位の変形が著しい 
と考兄られる。さらに $\eta_{2}$ の極大は結晶ラメラの上じれ ほどけを暗示しているのであろう。この結果はStein ら の動的 X 線回折法による動的配向係数 の皮膜の静的に 印加される伸張率依存性の結果 ${ }^{933}$ とよく対応している。

第 28 図恄晶b軸委わりの回転の非回復率 $\gamma_{2}$ の伸

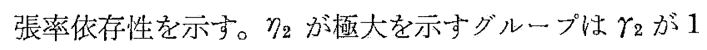
以下を示し弾性回復性を示し，極大を走さないグループ は 1 ないしは 1 より大きく，結晶 b軸まわりの変形が塑 性変形であるばかりでなくさらに再配向を考慮すべきこ とを暗示している。

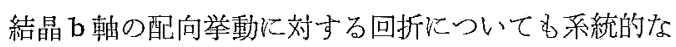
結果が得られている。

\section{0. 球晶変形モデルと配向分布 ${ }^{94)}$}

上述の球晶変形モデルに扔いては結晶各軸の延伸軸に 対する方向余弦の二乗平均により実験値との比較を行な った。しかしながら同じ配向係数であっても同じ配向分 布をるつとわかぎらない。したがてょり高次の配向係数 そ求めるか，直接配向分布に上り比较を行ならことが最 近試みられている。微結晶に対する任意の逆格子ベクル トの分布が得られるという点を利用して，Roe らによ る級数展開による方法を用いる。Legendre の多頂式に 展開したときの展開係数を $w_{2 l}$ とし, 配向単位の延伸軸 に対する分布関数を $N\left(\Omega_{2}\right)$ とすると単純一軸配向の場 合次式となる。

$$
\begin{gathered}
w_{2 l}=\int_{0}^{\pi} N\left(\Omega_{\lambda}\right) P_{2 l}\left(\cos \Omega_{\lambda}\right) \sin \Omega_{\lambda} d \Omega_{\lambda} \\
\text { ここで } j \text { 番目の結晶軸沉対する展開係数は } \\
Q_{2 l}{ }^{j}=w_{2 l} P_{2 l}\left(\cos \Theta_{j}\right)
\end{gathered}
$$

ここに $\Theta_{j}$ 配向単位と $j$ 番目の結晶軸とのなす角で ある。したがって $j$ 番目の結晶輣の配向分布関数 $q_{j}$ は 次式となる。

$$
q_{i}\left(\cos \Omega_{\lambda}\right)=\sum_{l=0}^{\infty} Q_{2 l}^{j} P_{2 l}\left(\cos \Omega_{\lambda}\right) \frac{4 l+1}{2}
$$

\section{1. おわりに}

以上前半に抒いて結晶性高分子の变形機構を種々の楧 造単位から㭘討を行ない, 後半で球晶変形のモデル的な 取扱について述べた。序にも述べたように未知の面があ まりにも多く，独断的な推諭を多く含んだ。特に結晶性 高分子に拉いても非晶鎖（あるいは領域）の变形に対す る寄与は大きいと考兄られ，いかにして知見を得るが 残された大きな問題である。

後半に述べた球晶变形に対するモデル的表現以変形に 伴う光学的性質あるいは力学的性質な物理的性質の变化 を定量化するばかりでなく、変形機構, ひいては構造を 解明するために重要な課題であるう。最近では電子計算 機が普及しモデル計算が非常に容易となった。したがっ
て具体的な球晶変形モデルにより力学的性質の理論計算 を行ない，逆に非結晶鎖の性状の推定を行ならこともで きよう。さらに最後にふれたた配向分布関数の段階で契測 值とモデル計算から得られる值を比較検討することはよ り戦密で多くの情報が得られる。

\section{文献}

1) E.W. Fischer: J. Polymer Sci., 34, 721 (1959); E.P. Pice: J. Polymer Sci., 37, 71 (1959); 39, 139 (1959); H.D. Keith, F. J. Padden: J. Polymer Sci., 39, 101, 123 (1959); A. Keller: J. Polymer Sci., 17, 291, 351, 447 (1955); Y. Fujiwara: J. Appl. Polymer Sci., 4, 10 (1960); A. Keller, S. Sawada: Makromol. Chem., 74, 174 (1964)

2) P.H. Geil: Polymer Single Crystal, Ch. 4 and 7, Interscience, New York (1963); 瀬戸, 高分 子物性 II（小野木他編，化学同人), Ch. 7, pp. 161 (1965)

3) 小田隆, 河合弘妯: 䋐継学会誌, 瀻維亡工業, 21, S 287 (1965)

4) R.S. Stein: J. Polymer Sci., C 15, 185 (1966)

5) P.H. Lindenmeyer, S. Lustig: J. Appl. Polymer Sci., 9, 227 (1965); J.L. Cooney: J. Appl. Polymer Sci., 8, 1889(1964); 高原弘和, 山口 豊, 福島昭夫, 河合弘赵: 瀻学誌, 印刷中

6) I. L. Hay, A. Keller: Kolloid-Z. Z. fïr Poly., 204, 43 (1965)

7) R. J. Samuels: J. Polymer Sci., A 3, 1741 (1965); 6, A-2, 1101 (1968)

8) K. O'Leary, P. H. Geil: J. Macromol. Sci.-Phys., B2 (2), 261 (1968)

9) H.D. Keith, J. Padden: J. Polymer Sci., 41, 525 (1959)

10) Y.F. Yu, P. Ullman: J. Polymer Sci., 60, 55 (1962)

11) P.H. Harris, J.H. Magill: J. Polymer Sci., 54, S 47 (1961)

12) K. Kobayashi, T. Nagasawa: J. Polymer Sci., C 15, 163 (1966)

13）小林恵之助：高分子の物性 (中島地編)，Ch. 11, 216 (1962)

14) I. Ingram, A. Peterlin: J. Polymer Sci., B 2, 739 (1964)

15）高島直一：高分子，12，663 (1963)

16) J.A. Runsock, J.A. D. Hansen: J. Polymer Sci., A 3, 647 (1965)

17) R. G. Crysta1, D. Hansen: J. Appl. Phys., 38, 
3103 (1967)

18) R. G. Crysta1, D. Hansen: J. Polymer Sci., 6, A-2, 981 (1968)

19) Y.A. Zubov et a1.: J. Polymer Sci.. C 16, 2215 (1967)

20) R.S. Moore: J. Polymer Sci., A 1, 4093 (1965)

21）木下茂武，馬越 淳：綫学誌，23，189（1967）

22) R.S. Stein, M. B. Rhođes: J. Appl. Phys., 31, 1873 (1960); R.S. Stein et al.: J. Polymer Sci., C 13, 1 (1966)

23) R. J. Samuels: J. Polymer Sci., C13, 37 (1966)

24）小田 隆，坂口亘弘，河合弘赵：高化， 25, 588 (1968)

26) R.S. Moore, C. Gieniewski: J. Polymer Sci., C 13, 55 (1966); R.S. Moore, C. Gieniewski: J. Appl. Phys., 36, 3022 (1965)

27）小田隆，茂木正彦，森谷稚彦，河合弘廸：高化， 25, 639 (1968)

28) R.S. Moore: J. Polymer Sci., 5, A-2, 711 (1967)

29) A. J. Brown: J. Appl. Phy., 20, 552 (1949)

30) H. A. Nancarrow, R. A. Horstey: Brit. J. Appl. Phys., 2, 345 (1951)

31) S. L. Aggarwal, G. P. Tilley, O. J. Sweeting: J. Appl. Polymer Sci., 1, 91 (1959)

32) S. L. Aggarwal, G. P. Tilley, O. J. Swaeting: J. Polymer Sci., 51, 551 (1961)

33) S. Hoshino et a1.: J. Polymer Sci., 58, 185(1962)

34) I. L. Hay, A. Keller: J. Mater. Sci., 1, 41 (1966)

35) B. A. Belbeoch, Guinier: Makromol. Chem., 31, 1 (1959)

36) A. Keller: J. Polymer Sci., 21, 401 (1956)

37) N. Kasai, M. Kakudo: J. Polymer Sci., A 2, 1955 (1964)

38) N. Kasai, M. Kakudo: Repts. Progr. Polymer Phys. Japan, 9, 239 (1966)

39) W.W. Moseley: J. Appl. Polymer Sci., 3, 266(1960)

40) R.S. Stein, F.H. Norris: J. Polymer Sci., 21, 381 (1956); R.S. Stein: J. Polymer Sci., 31, 335 (1958)

41) P.H. Hermans, P. Platzek: Kolloid-Z., 88, 68 (1938)

42) R. A. Sack: J. Polymer Sci., 54, 543 (1961); Z. W. Wilchinsky: J. Appl. Phys., 30, 792 (1959); S. Nomura, H. Kawai, I. Kimura, M. Kagiyama: J. Polymer Sci., 5, A-2, 479 (1967); C. R. Desper, R. S. Stein: J. Appl. Phys., 37, 3990 (1966)

43）角戸正夫，鉴牛暢民：高分子 X線回折，丸善，Ch.
10 (1967)

44）高原弘和，河合弘赵：䋐維と工業， 21，S 120, S 177, S 235 (1965); 河合弘妯, 野村 : 繊維 と工業, 22, S 266, S 309 (1966)

45) K. Fujino, H. Kawai, T. Oda, H. Maeda: Proc. 4th. Intern. Cong. Rheo., (E. H. Leed) Wiley New York, Part 3, 551 (1965)

46) A. Peterlin, K. Sakaoku: Kolloid-Z., 212, 51 (1966); J. Appl. Phys., 38, 4152 (1967); K. Sakaoku, A. Peterlin: J. Macromol. Sci., B 1, 103 (1967)

47) I. Hay, A. Keller: Nature, 204, 862 (1964)

48) S. N. Zhurkov, et a1.: Soviet Phys. Doklady, 8, 1083 (1964); Soviet Phys. Solid State, 6, 2881 (1965)

49) T. Oda, S. Nomura, H. Kawai: J. Polymer Sci., A 3, 1943 (1965)

50）高原弘和, 河合弘廸, 山田哲三 : 繊学誌, 23,102 (1967)； 24, 219 (1968)

51) S. Nomura, H. Kawai: J. Polymer Sci., 4, A -2, 797 (1966)

52）高原弘和, 河合弘妯, 打田哲三：繊学誌, 24, 261 (1968)

53) W. R. Krigbaum: J. Polymer Sci., C 15, 251 (1966)

54）坂口文雄, 辻 和一郎：高化，23，836（1966）

55) O. Kratky: Kollod-Z., 64, 213 (1933)

56) T. Oda, N. Sakaguchi, H. Kawai: J. Polymer Sci., C 15, 232 (1966)

57) H. Kawai, T. Oda, S. Nomura, T. Hashimoto: Pre-print of Scientific paper presented before the Intern, Synposium Macro. Chem. TokyoKyoto, VIII, 90 (1966)

58）高原弘和，河合弘妯，山田哲三：䋞学誌，24，269 (1968)

59) M. Takayanagi: Memoirs of the Faculty of Engineering, Kyushu Univ., 23, 41 (1963)

60) T. Oda, H. Kawai: Repts. Progr. Polymer Phys. Japan, 10, 219 (1967)

61) T. Oda, H. Kawai: Repts, Progr. Polymer Phys. Japan, 11, 187 (1968)

62) O. Hendus: Kolloid-Z., 165, 32 (1959)

63) I. Hay, A. Keller: J. Matls. Sci., 2, 538 (1967)

64) E.W. Fischer, G. H. Schmidt: Angew. Chem., 74, 551 (1962)

65) I. Hay, T. Kawai, A. Keller: J. Polymer Sci., C 16, 2721 (1967)

66) R. Yang, R.S. Stein: J. Polymer Sci., 5, A-2, 
939 (1967)

67) K. Sasakuri, S. Hoshino, R. S. Stein: J. Appl. Phys., 5, 47 (1964)

68) P.H. Geil: 文献 2), Ch.7, pp 441; P.H. Geil: J. Polymer Sci., A 2, 3813 (1964); A 2, 3835 (1964)

69) P.H. Geil: J. Polymer Sci., A 2, 3857 (1964)

70) P. H. Geil, H. Kiho, A. Peterlin: J. Polymer Sci., B 2, 71 (1964); H. Kiho, A. Peterlin, P. H. Geil: J. Appl. Phys., 35, 1599 (1964)

71) H. Kiho, A. Peterlin, P.H. Geil: J. Polymer Sci., B 3, 157 (1965)

72) H. Kiho, A. Peterlin, P.H. Geil: J. Polymer Sci., B 3, 257 (1965)

73) H. Kiho, A. Peterlin, P.H. Geil: J. Polymer Sci., B 3, 263 (1965)

74) A. Peterlin: J. Polymer Sci., C 15, 427 (1966)

75) A. Pelerlin: J. Polymer Sci., C 16, 1857 (1966)

76) T. Seto et al.: Japan J. Appl. Phys., 5, 534 (1966); 7, 31 (1968)

77) T. Ito, N. Sugiura, H. Kawai: J. Polymer Sci., to be submitted

78) F. C. Frank, A. Keller, A. O’Connor: Phil. Mag., 3, 64 (1958)

79）瀬戸恒夫：高分子，13，45（1964）

80) H. Kawai: Generallecture presented before 5th Intern. Cong. Rheology, Kyoto, Oct. 1968; to be published in proc. of 5 th Intern. Cong. on Rheology.

81）野村春治，河合弘妯：第 17 回高分子討論会前刷, pp. 767 (1968)

82) W. Kuhn, F. Grun: Kolloid-Z., 101, 248 (1942)

83) Z.W. Wilchinsky: Polymer (London), 5, 271 (1964)

84) K. Sasaguri, R. Yamada, R. S. Stein: J. Appl. Phys., 35, 3188 (1964)

85）高原弘和, 河合弘柚, 山田哲三：緎学誌, 24, 311 (1968)

86）高原弘和，山口 豊，福島昭夫，河合弘廸：緎学 誌，投稿中

87）佐藤良泰：材料，物性論研究

88) T. Oda, H. Kawai: Kolloid-Z. für Polymere, to be submitted

89) R. A. V. Raff, J.B. Allison: "Polyethylene", Interscience, New York, Ch. 6, p 235 (1956)

90) M. Takayanagi, T. Matsuo: J. Macromol. SciPhys., B 1, 407 (1967); V.F., Holland, P.H. Lindenmeyer: J. Appl. Phys., B 6, (1965); Phys. slat. sol., 10, 543 (1965)

91) 圾奥喜一郎：学位論文 (京都大学) (1964)

92) 大屋根，小島：金属材料の破壞，日本金 属学会, Ch. 3, P. 123 (1964)

93) I. Kimura, R. S. Stein: Pre-print presented before the 5th Intern. Cong. Rheo., Kyoto

94）野村春治，末広祥二，浅沼 明，河合弘赵：第 17 回高分子討論会予稿集，松山，p.761 (1968)

\section{会費·購読費の納入について}

昭和 44 年 12 月 31 日で下記の方々が会費切れと なりました。

a. 該当者

i） 1 力年分（昭和 44 年 1 月～43 年12月）の正会費 または購読費を納めている方。

ii）半力年分（昭和 44 年 7 月〜 12月）の正会費京た は購読費を納めている方。

b. 送金方法

i) 拨替用紙を使用されるのが最も便利です。その他 現金など (小切手・為替) の場合は必ず書留で捄送 り下さい（書留以外の場合, 事故発生があっても責 任は負いません)。

ii）振替用紙の通信欄には，氏名・会員番号・送金の 明細を必ずご記入下さい。

iii）銀行振込の場合は会貝名（個人名）を記入した落 㰦通知状を必ず本会会員係あてご提出下さい。

iv) 送付先は 高分子学会会員係 (期便番号 104, 東 京都中央区銀座 5-12-8 本州ビル 4 階)
電話による排問合せは会員係へねがいます。 東京 (03) (543) 3771(代)

\begin{tabular}{|c|c|c|}
\hline & $\left(\begin{array}{c}1 \text { 力年 } \\
\text { 昭和 } 45 \text { 年上期 } \\
\text { 其 }\end{array}\right.$ & $\begin{array}{c}\text { 半力年 } \\
\text { 昭和 } 45 \text { 年 } \\
\text { 上期のみ }\end{array}$ \\
\hline 正会費 & 2,200 & 1,100 \\
\hline $\begin{array}{l}\text { 「高分子化学」購読費 } \\
\text { 「海外高分子研究」 }\end{array}$ & 2,400 & 1,200 \\
\hline 購読費 & 2,300 & 1,150 \\
\hline
\end{tabular}

d. ご注意

会費・購読費を納入された場合，受領書は原則とし て発行いたしておりをせん。したがって郵便局などで の受領書は手元に保存していただくよう拓願いいたし ます。

な扣，学会発行の受領書を必要とする方は，その旨 学会あてに拉申し出下さい。 